\title{
Impact of energy restriction during late gestation on the muscle and blood transcriptome of beef calves after preconditioning
}

Leticia P Sanglard ${ }^{1,2}$, Moysés Nascimento ${ }^{2,3}$, Philipe Moriell, Jeffrey Sommer ${ }^{2}$, Melissa Ashwell ${ }^{2}$, Matthew H Poore ${ }^{2}$, Márcio de S Duarte ${ }^{5,6}$ and Nick V L Serão ${ }^{1,2^{*}}$ (D)

\begin{abstract}
Background: Maternal nutrition has been highlighted as one of the main factors affecting intra-uterine environment. The increase in nutritional requirements by beef cows during late gestation can cause nutritional deficiency in the fetus and impact the fetal regulation of genes associated with myogenesis and immune response.

Methods: Forty days before the expected calving date, cows were assigned to one of two diets: $100 \%$ (control) or 70\% (restricted group) of the daily energy requirement. Muscle samples were collected from 12 heifers and 12 steers, and blood samples were collected from 12 steers. The objective of this work was to identify and to assess the biological relevance of differentially expressed genes (DEG) in the skeletal muscle and blood of beef calves born from cows that experienced [or not] a 30\% energy restriction during the last 40 days of gestation.

Results: A total of 160, 164, and 346 DEG ( $q$-value< 0.05 ) were identified in the skeletal muscle for the effects of diet, sex, and diet-by-sex interaction, respectively. For blood, 452, 1392, and 155 DEG were identified for the effects of diet, time, and diet-by-time interaction, respectively. For skeletal muscle, results based on diet identified genes involved in muscle metabolism. In muscle, from the 10 most DEG down-regulated in the energy-restricted group (REST), we identified 5 genes associated with muscle metabolism and development: SLCO3A1, ATP6VOD1, SLC2A1, GPC4, and RASD2. In blood, among the 10 most DEG, we found genes related to response to stress up-regulated in the REST after weaning, such as SOD3 and INO80D, and to immune response down-regulated in the REST after vaccination, such as OASL, KLRF1, and LOC104968634.

Conclusion: In conclusion, maternal energy restriction during late gestation may limit the expression of genes in the muscle and increase expression in the blood of calves. In addition, enrichment analysis showed that a short-term maternal energy restriction during pregnancy affects the expression of genes related to energy metabolism and muscle contraction, and immunity and stress response in the blood. Therefore, alterations in the intra-uterine environment can modify prenatal development with lasting consequences to adult life.
\end{abstract}

Keywords: RNA-seq, Fetal development, Fetal programming, Gene expression

\footnotetext{
* Correspondence: serao@iastate.edu

'Department of Animal Science, lowa State University, Ames 50011, USA

2Department of Animal Science, North Carolina State University, Raleigh

27695, USA

Full list of author information is available at the end of the article
}

(c) The Author(s). 2018 Open Access This article is distributed under the terms of the Creative Commons Attribution 4.0 International License (http://creativecommons.org/licenses/by/4.0/), which permits unrestricted use, distribution, and reproduction in any medium, provided you give appropriate credit to the original author(s) and the source, provide a link to the Creative Commons license, and indicate if changes were made. The Creative Commons Public Domain Dedication waiver (http://creativecommons.org/publicdomain/zero/1.0/) applies to the data made available in this article, unless otherwise stated. 


\section{Background}

Maternal nutrition has been highlighted as one of the main factors affecting the intra-uterine environment [1]. There is an increase in nutritional requirements of beef cows during late gestation [2], and if not met, the limited amount of nutrients available for optimum fetal development may affect prenatal physiological functions and, consequently, result in impaired post-natal growth and performance of the offspring [3, 4]. The last trimester of gestation is therefore a critical period for fetal growth [3].

Metabolizable energy restriction has been shown to down-regulate the mitogenic responses of $\mathrm{T}$ lymphocytes in beef calves $[4,5]$. Prenatal programming of physiological systems can alter the growth and the function of organs and pathology into adulthood [6]. In other words, nutritional deficiency may impact the regulation of genes associated with myogenesis and immune response in the fetus, which can have long-term effects on progeny performance [3].

The deposition of skeletal muscle has significant implications to the animal meat-production systems. Muscle fibers are formed mainly during mid-gestation, and the definitive number of fibers is determined before birth [7]. On the other hand, fiber hypertrophy occurs during the late gestational period and continues following birth [7]. In addition, since a well-developed immune system protects the animal from pathogens and other stressors, healthy animals present better performance compared to compromised animals during growth and development [8]. Moreover, the prenatal programming of the immune system would give rise to changes that persist over the course of the animal's life [9].

Transcriptome studies have shown changes in fetal growth and immune factors, especially during the final trimester of gestation. Studies have reported differentially expressed genes (DEG) in the muscle of the fetus as an effect of different energy sources in maternal diets, which ultimately change the metabolizable energy intake $[9,10]$. For example, a decrease in expression of genes involved in muscle synthesis and differentiation, tissue and organ development, chromatin biology, and metabolic processes have been reported in calves as an effect of maternal diet during pregnancy based on corn compared with a diet based on alfalfa haylage, and dried corn distillers grains [10]. In addition, O'Loughlin et al. [11] identified DEG involved in cytokine signaling, transmembrane transport, hemostasis and G-protein-coupled receptor signaling as a response to weaning stress in calves.

The preconditioning phase is a critical period for beef calves, since animals pass through stressful procedures such as vaccination, weaning, and diet changes [12, 13]. As a response, there is a mobilization of protein from muscle [14] to increase the synthesis of proteins and cells involved in the immune system [15]. Consequently, the growth performance is compromised due to limited availability of nutrients to skeletal muscle development. Also during this period, there is a decrease in energy and protein intake [16] which may reduce the immune capacity of the animal and, consequently, impacts the vaccination response [13].

We hypothesized that maternal energy restriction would cause changes in the expression of genes related to muscle development and immune response in preconditioned beef calves born from cows that experienced [or not] a short-term energy restriction (30\% of total energy requirements) during the last $40 \mathrm{~d}$ of gestation. Therefore, the objectives of this work were (1) to identify DEG in the muscle and blood of beef calves born from cows with and without energy restriction, (2) to assess the biological relevance of DEG, and (3) to investigate the relationships of DEG through gene networks.

\section{Methods}

The animal trial was conducted at the Mountain Research Station (Waynesville, NC; $35.48^{\circ} \mathrm{N}, 82.99^{\circ} \mathrm{W}$; elevation $659 \mathrm{~m}$ ) at North Carolina State University, from January to November 2015, using animals from its research herd. The study was conducted in compliance with all welfare regulations, with all the study procedures being approved by the Institutional Animal Care and Use Committee of North Carolina State University (15-054-A). After the study, all animals returned to the research herd.

\section{Animals and diets}

Thirty receptors multiparous, nonlactating, spring-calving pregnant Angus cows with an average body weight of 631 $\pm 15 \mathrm{~kg}$, age of $5.2 \pm 0.98$ years, and body condition score of $6.3 \pm 0.12$ were used in this study. Cows were sired by two sires, and forty days before the expected calving date, the cows were randomly assigned to one of the two isonitrogenous diets: the control group (CTRL) and the restricted group (REST). Animals received total-mixed diets formulated to provide $100 \%$ (CTRL) or $70 \%$ (REST) of the daily net energy requirement for maintenance of a $630 \mathrm{~kg}$ beef cow at 8 months of gestation [17]. Animals were randomly assigned to pens according to the treatment ( $n=5$ pens/treatment). Immediately after calving, cow-calf pairs were transferred to 1 of 6 tall fescue pastures with free choice access to water and a complete mineral mix. Cows received dietary treatments for $40 \pm 5.1$ days. All male calves were castrated by banding immediately after birth. Cows and calves were managed as a single group and rotated among pastures monthly from calving until weaning (approximately 227 days of age). From weaning (day 0) until 40 days post weaning (dpw), calves were assigned to a preconditioning period. Additional detailed information regarding the nutritional information of the diets, feeding 
strategies, and the design of the study has been described in Moriel et al. [18] .

\section{Preconditioning}

At weaning (0 dpw), calves were individually treated with doramectin for internal and external parasites (5 mL subcutaneous; Dectomax injectable; Zoetis Inc., Kalamazoo, MI). At $8 \mathrm{dpw}$, calves were vaccinated against infectious bovine rhinotracheitis virus, bovine viral diarrhea virus types $1 \mathrm{a}$ and 2 , parainfuenza 3 virus, Mannheimia haemolytica (2 mL subcutaneous; Bovi Shield Gold One Shot; Zoetis Inc.), and Clostridium spp. (2 mL subcutaneous; Ultrabac 7; Zoetis Inc.). At $21 \mathrm{dpw}$, calves received $2 \mathrm{~mL}$ subcutaneous boosters of Bovi Shield Gold 5 (Zoetis Inc.) and Ultrabac 7. This vaccination protocol was used to replicate the standard protocol used by the local preconditioning alliance (Mountain Cattle Alliance, Canton, NC) $[19,20]$.

\section{Tissue collection}

At $21 \mathrm{dpw}$, a biopsy of the skeletal muscle Longissimus dorsi was performed in all calves (12 steers and 12 heifers) at the level of the pelvis between the iliac, coxal and ischial tuberosity to obtain a minimum sample of tissue for subsequent gene expression analysis. The muscle biopsies were placed into a $2 \mathrm{~mL}$ Cryovial tube containing RNAlater (Ambion Inc., Austin, TX, USA) and stored in a $-20{ }^{\circ} \mathrm{C}$ freezer for subsequent laboratory analysis. In addition, the blood samples $(10 \mathrm{~mL})$ were collected from all steers via jugular venipuncture into Tempus Blood RNA Tubes (Life Technologies, Carlsbad, CA, USA) at $0,3,6$, and $15 \mathrm{dpw}$ for subsequent gene expression analysis. Blood samples were immediately put on ice and stored at $-80{ }^{\circ} \mathrm{C}$ until later laboratory analysis. Although 30 cows were initially used in the trial, subsequent analyses were performed on a subset of samples in order to reduce costs. Thus, a random sample of 24 calves (12 steers and 12 heifers) and 12 steers (one from each pen) were used for muscle and blood analyses, respectively. Since, we had four time points for blood, we opted to analyze just one sex to avoid increasing the complexity of the statistical models and the excessive costs.

\section{RNA extraction, sequencing, and bioinformatics}

Total RNA from muscle and blood samples were extracted using RNeasy Fibrous Tissue Mini Kit (Qiagen Inc., Germantown, MD, USA) and Tempus ${ }^{\mathrm{Tm}}$ RNA isolation kit (Applied Biosystems, Foster City, CA, USA), respectively. The RNA quantity and quality were determined by Agilent 2100 Bioanalyzer (Agilent Technologies, Inc., Santa Clara, CA, USA). One muscle and one blood sample were excluded from subsequent analysis due to low RNA integrity number (RIN) score $(\mathrm{RIN}<8)$.
All remaining samples were sent out to the Genomic Sciences Laboratory (North Carolina State University, Raleigh, NC, USA) for library construction and RNA-sequencing. Sequencing was performed on an Illumina NextSeq 500 instrument (Illumina, Inc., San Diego, USA), generating $75 \mathrm{bp}$ paired-reads and $150 \mathrm{bp}$ single-end reads for muscle and blood, respectively. The difference was to avoid excessive cost with the paired-end analysis since we had higher number of samples and it has been proposed that single-ends are sufficient to detect difference in expression in RNA-seq analysis. A total of 2 and 3 flow cells were used, respectively, for muscle and blood samples, with approximate equal representation of treatments between flow cells.

The quality of raw reads were evaluated with FastQC [21]. Sequence reads for each sample were mapped to Bos taurus UMD3.1 reference genome using Bowtie2 [22]. The number of counts for each sample was obtained with the Subread package from SourceForge [23]. A total of 2,076,680,240 paired-ends and 1,353,110,288 single-ends reads were generated for muscle and blood samples, respectively, with an average of 90,290,445 and $28,789,580$ reads/sample, respectively. Reads were mapped to a total of 19,045 genes $(77.43 \%)$ and 19,331 genes $(78.59 \%)$ for muscle and blood, respectively. This was from a total of 24,596 genes annotated in the Bos taurus reference genome UMD3.1. Genes with a total of counts less than four times the number of samples were eliminated to avoid low counts across multiple samples, resulting in a final set of 15,255 and 13,512 genes for muscle and blood, respectively. For normalization of the data, we used the Trimmed Mean of M-values (TMM) to calculate the normalized factors (TCC package [24]). The normalized library size was obtained by dividing the total library size by the normalized factors.

\section{Statistical analyses}

Gene expression data was analyzed with a negative binomial model with a log link function [25]. Different models were tested for each tissue. For muscle, a negative binomial function was used in the following model:

$$
\begin{aligned}
Y_{i j k l m n}=\mu & +D_{i}+S_{j}+(D * S)_{i j}+B_{k}+P_{l} \\
& +\beta_{1}\left(R_{i j k l m n}-\bar{R}\right)+\beta_{2}\left(D O T_{i j k l m n}-\overline{D O T}\right) \\
& +S S_{n}+\log \left(L_{i j k l m n}\right)+\varepsilon_{i j k l m n}
\end{aligned}
$$

where, $Y_{i j k l m n}$ is the raw number of counts; $\mu$ is the intercept, $D_{i}$ is the fixed-effect of the $\mathrm{i}^{\text {th }}$ Diet; $S_{j}$ is the fixed effect of the $\mathrm{j}^{\text {th }}$ Sex; $B_{k}$ is the fixed effect of the $\mathrm{k}^{\text {th }}$ Batch (sequencing lane); $P_{l}$ is the fixed effect of the $1^{\text {th }}$ Pen; $\beta_{1}$ is the partial regression coefficient for the covariate RIN scores $(R) ; \beta_{2}$ is the partial regression coefficient for the 
covariate Days on Dietary Treatment (DOT); $S S_{n}$ is the fixed effect of the ${ }^{\text {th }}$ Service Sire; $L_{i j k l m n}$ is the TMMnormalized library size, used as an offset; and $\varepsilon$ is the random residual associated with $Y_{i j l k m n}$. In addition to this model, 3 other reduced models were tested, in which the effects of pen and/or the interaction were removed. All models were used for each of the 15,255 genes, and the final model for each gene was chosen based on Akaike information criterion (AIC).

For the gene expression analysis of blood samples, a negative binomial function was used in the following model:

$$
\begin{aligned}
Y_{i j k l m n}=\mu & +D_{i}+T_{j}+(D * T)_{i j}+B_{k} \\
& +\beta_{1}\left(R_{i j k l m n}-\bar{R}\right)+\beta_{2}\left(D O T_{i j k l m n}-\overline{D O T}\right) \\
& +S S_{n}+\log \left(L_{i j k l m n}\right)+\varepsilon_{i j k l m n}
\end{aligned}
$$

where, $Y_{i j k l m n}, \mu, D, B_{k}, \beta_{1}, R_{i j k l m n}, D O T_{i j k l m n}, S S_{n}, L_{i j k l m n}$ and $\varepsilon_{i j k l m n}$ are as previously defined. $T_{j}$ is the fixed effect of the $\mathrm{j}^{\text {th }}$ Time. A reduced model without interaction was tested, and analyses were performed using three covariance structures for the residuals: first-order autoregressive, compound symmetry, and independent residuals. Therefore, 6 models were tested for each of the 13,512 genes, and the final model for each gene was selected based on AIC. Satterthwaite approximation to account for sample variances was used to determine the denominator degrees of freedom (df). The dispersion parameter of the model was calculated for each gene squeezing towards a global dispersion with an approach assuming mean and variance related by $\sigma^{2}=\mu+a \mu^{2}$ [26], where $a$ is a proportiallity constant, using the package edgeR in $\mathrm{R}$ software [27].

Additional contrasts were constructed in order to answer biologically relevant questions in the analysis of blood samples. Contrasts were developed for both the interaction effect (diet-by-time) and the main effect of time. For the main effect of time, two contrasts with 1-df were constructed: (1) to test the effect of vaccination (i.e. average of days 0,3 , and 6 , versus day 15 ) and (2) to evaluate the acute response to weaning (i.e. day 0 versus average of days 3 and 6). For the interaction effect, these same contrasts were constructed, but accommodating their interaction with diet.

False-discovery rate (FDR [28]) was used to adjust the $P$-values ( $q$-values) of model terms due to multiple testing. Significant DEG were identified at $q$-value $\leq 0.05$ for all analyses. All data were analyzed using the GLIMMIX procedure of SAS 9.4 (Statistical Analysis System Institute, Inc., Cary, NC, USA).

\section{Functional annotation analysis}

The enrichment of Gene Ontology (GO) terms associated with DEG was analyzed using PANTHER Enrichment
Analysis [29]. Different DEG lists were created based on the significance $(q$-value $<0.05)$ of effects in the model. For the muscle data, analyses were performed separately for DEG based on diet and sex. For blood, we performed 3 analyses, one based on the effect of diet, and two based on the previously described contrasts (effect of vaccination and weaning). The Bos taurus genome was used as the background list. Biological Processes was considered significant at $P$-value $<0.05$.

\section{Gene-network analysis}

Genes networks were constructed for the effect of diet including all DEG in muscle and all DEG in muscle and blood. Then, due to the difficult visualization in the previous networks, we have created more two gene networks including the 20 most DEG in the muscle and the 10 most DEG for the effect of diet in muscle associated with the 10 most DEG in blood. Partial correlation networks were constructed using gene counts pre-adjusted for all effects in the model, with the exception of diet (the effect of interest). In other words, the data used in this analysis, for each individual, represented the sum of the estimated diet effect and its residual. For the network including DEG from muscle and blood tissues, only data from steers were used as only male offspring had data using both tissues. For the gene networks including all DEG, connections between genes (i.e. nodes) were included when a pair of genes showed a partial correlation greater than $|0.8|$. The correlation matrix and the gene-networks were constructed using the ppcor [30] and qgraph [31] packages in R software [27].

\section{Results and discussion}

Alterations in the intra-uterine environment, such as those caused by maternal nutrition during pregnancy, can modify prenatal development, which can lead to positive or negative consequences to the adult life of the animal $[2,32]$. In addition to the prenatal susceptibility, the pre-conditioning phase is also critical for offspring development since the animal is going through a stressful period and may have its performance compromised. Therefore, a well-developed immune system, associated with proper development of muscle tissue, would favor the productive performance of the animal. Our study focused on the effect of maternal energy restriction during late gestation on the transcriptomic profile in the skeletal muscle and blood tissues in the offspring.

\section{DEG identification}

The number of DEG identified in this study is shown in Fig. 1. A total of 160, 164, and 346 DEG ( $q$-value $<0.05$ ) were identified in the muscle for the effects of diet, sex, and diet-by-sex interaction, respectively (Fig. 1a). For blood, 452, 1392, and 155 DEG ( $q$-value <0.05) were 
A

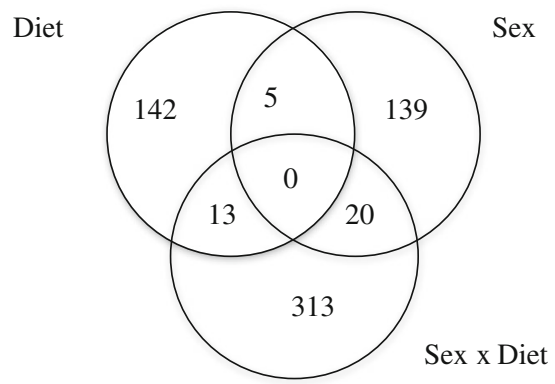

B

Diet

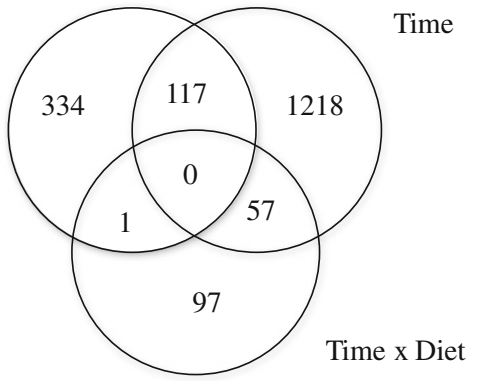

Fig. 1 Venn Diagram with the number of differentially expressed genes (DEG; $q$-value $<0.05$ ) for the effects of diet, sex, and diet-by-sex for muscle (a), and diet, sex and diet-by-time for blood (b)

identified for the effects of diet, time, and diet-by-time interaction, respectively (Fig. 1b). For the contrasts in blood tissue, there were 101 and 47 DEG $(P$-value $<0.05)$ for Weaning and Vaccination, respectively, based on the diet-by-time interaction effect $(q$-value $<0.05)$. For the main effect of Time ( $q$-value $<0.05)$, there were 893 and 473 DEG ( $P$-value $<0.05)$ for the Weaning and Vaccination contrasts, respectively.

The volcano plots for the effect of diet are shown in Fig. 2. For the effect of sex in the muscle, there was a greater number of up-regulated genes in the females (117) compared with males (47; Fig. 2a). For the effect of diet, there was a greater number of down-regulated (131) genes in the REST compared to up-regulated (29) in the muscle tissue (Fig. 2b), suggesting that maternal energy restriction during late gestation may limit the expression of genes in the muscle of calves. In contrast, there was a much greater number of up-regulated genes in the REST (410) compared to down-regulated (42) in the blood (Fig. 2c). Although we do not have the data to conclude on this, this clear gene-regulation bias towards one diet or the other could be due to maternal energy restriction causing epigenetic modifications in the fetal genome.

\section{Enrichment analyses in the muscle}

The results of the enrichment analysis for diet and sex are presented in Table 1 . Results based on diet $(P<0.05)$ showed genes involved in the metabolisms of energy and muscle, i.e. positive regulation of actin cytoskeleton reorganization (GO:2000251), positive regulation of collagen biosynthetic process (GO:0032967), adipose tissue development (GO:0060612) and positive regulation of collagen metabolic process (GO:0010714); and nervous system metabolism, i.e. regulation of neuron differentiation (GO:0045664), regulation of neurogenesis (GO:0050767), regulation of nervous system development (GO:0051960), and negative regulation of neuron projection development (GO:0010977). Enrichment analyses for the effect of sex showed that the DEG were enriched for categories related to acid nucleic metabolic process, such as histone H3-K27 demethylation (GO:0071557), DNA-dependent DNA replication (GO:0006261), DNA replication initiation (GO:0006270), and DNA repair (GO:0006281); and metabolism of carbohydrate and muscle, such as positive regulation of glycoprotein biosynthetic process (GO:001 0560), regulation of skeletal muscle contraction (GO:00 14819), and regulation of glycogen metabolic process (GO:0070873). These functional terms are related to chromatin biology and to epigenetics suggesting that these variations are responsible for the changes in the gene expression observed in the fetal tissues. Our study supports the hypothesis that males and females have different gene expression pattern during fetal development. The differences in offspring outcomes according to their sex as an effect of fetal programming has been reported in sheep $[33,34]$ and cows $[35,36]$. In this study however, we did not look at the effect of interaction diet-by-sex since, in the muscle analysis, few genes were selected for the model containing interaction. Additional results $(P<0.05)$ including biological function $\mathrm{GO}$ terms for the effects of diet and sex can be seen in Additional file 1 .

\section{Major DEG in the muscle}

The 10 most significant up- and down-regulated DEG in REST are summarized in Table 2. Of these, the most significant down- and up-regulated genes in the REST were SLCO3A1 and ETNPPL, with a fold change (FC) [95\% confidence interval] of 0.77 [0.71, 0.84] ( $q$-value $=$ $4.58 \mathrm{E}-07)$ and $1.32[1.18,1.48]$ ( $q$-value $=1.56 \mathrm{E}-04)$, respectively. The most extreme FC was observed for SPATA1, with $2.28[1.54,3.39] \quad(q$-value $=3.91 \mathrm{E}-03)$. From the 10 most down-regulated genes in REST, we identified 5 genes associated with muscle metabolism and development as well as with energy metabolism: (1) SLCO3A1, a membrane transporter of the thyroid hormone involved in satellite cell differentiation [37]; (2) ATP6VOD1, involved in oxidative phosphorylation [38]; (3) SLC2A1, a facilitator of glucose transport; (4) GPC4, involved in cell proliferation [39]; and (5) RASD2, expressed in satellite cells and involved in cellular 


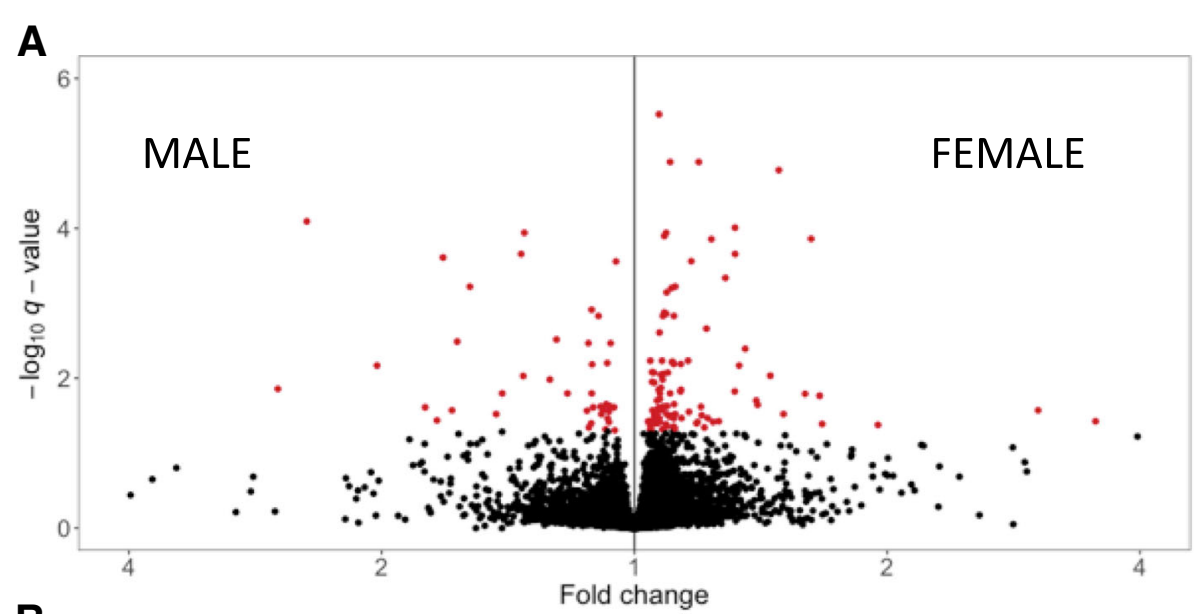

B

Fold change
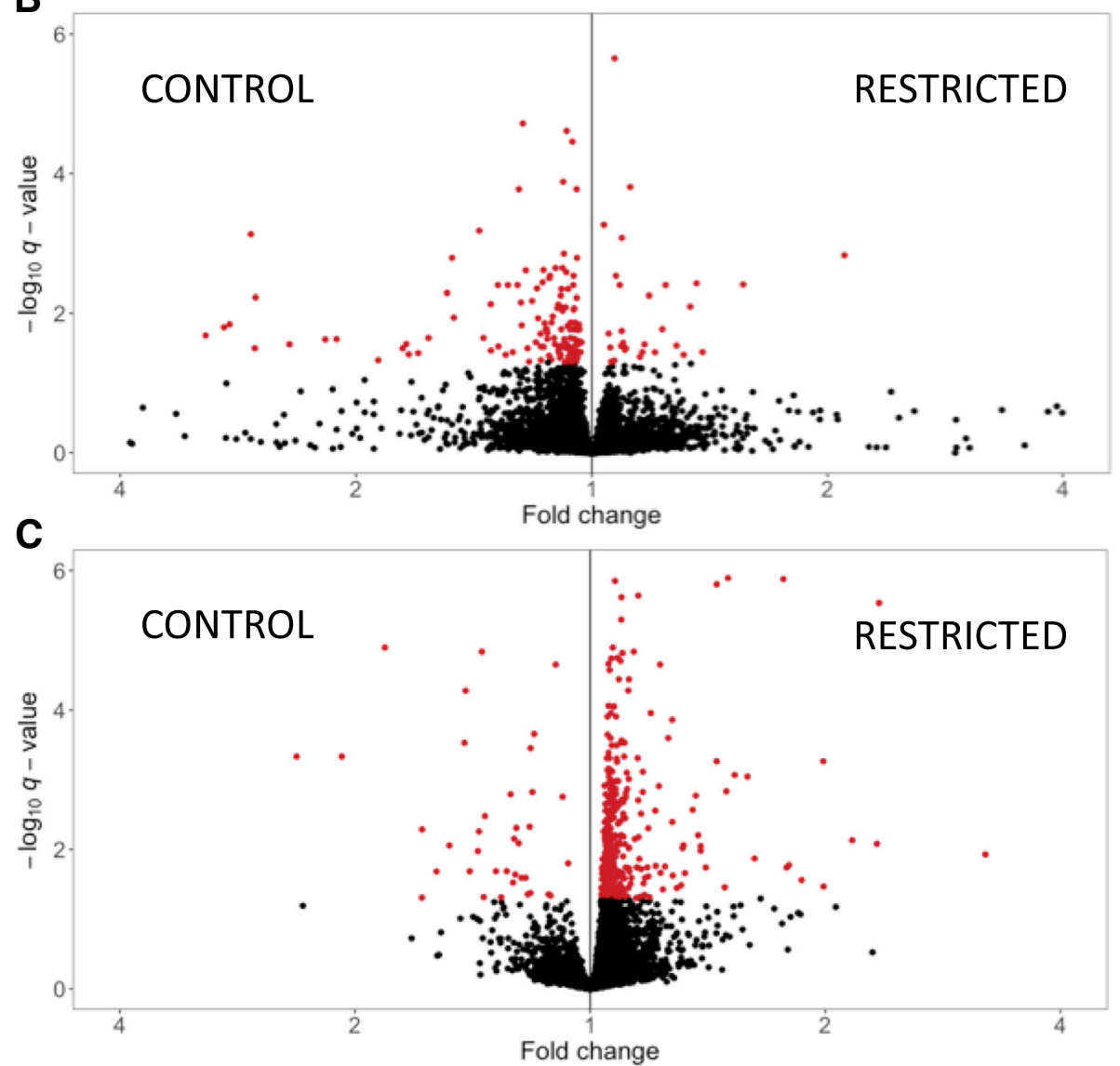

Fig. 2 Volcano plots for the effect of sex (a) and diet (b) in the muscle tissue, and for the effect of diet (c) in the blood tissue. The Y-axis shows the $-\log 10 q$-values for the effects of sex (a) or diet ( $\mathbf{b}$ and $\mathbf{c}$ ), whereas the $X$-axis represents the fold change (FC), with FC equal 1 representing equal expression between the two compared groups. In A, FC values to the left and right represent the up-regulation of DEG in male and female calves, respectively. In B and C, FC values to the left and right represent up-regulation of DEG in the control and restricted diets, respectively. Genes with significant ( $q$-value $<0.05)$ effect of diet are highlighted in red. Extreme values of FC $(<$ or $>5)$ and $q$-value $(<1.0 \mathrm{E}-06)$ were removed from the plot

movement and cell cycle. This connection of major genes with energy metabolism associated with the relevant functional terms in the enrichment analysis may indicate a shift in the way the tissues are generating energy in the REST compared with CRTL.
We propose that energy is being produced primarily through the glycolytic pathway instead of the oxidative pathway, which is less efficient and occurs as a result of lack of sufficient energy. Concordantly, Daniel et al. [40] showed that maternal dietary restriction during 
Table 1 Enrichment analysis showing 20 most overrepresented Biological Process for differentially expressed genes ${ }^{2}$ for the effects of diet and sex in the muscle tissue

\begin{tabular}{|c|c|c|c|}
\hline Biological Process & \# genes & $\mathrm{FE}$ & $P$-value \\
\hline \multicolumn{4}{|l|}{ Diet } \\
\hline $\begin{array}{l}\text { Positive regulation of actin cytoskeleton } \\
\text { reorganization (GO:2000251) }\end{array}$ & 2 & 21.68 & 4.88E-03 \\
\hline $\begin{array}{l}\text { Peptidyl-proline hydroxylation } \\
\text { (GO:0019511) }\end{array}$ & 2 & 21.68 & 4.88E-03 \\
\hline $\begin{array}{l}\text { Positive regulation of blood vessel } \\
\text { endothelial cell migration (GO:0043536) }\end{array}$ & 3 & 13.21 & 1.90E-03 \\
\hline $\begin{array}{l}\text { Negative regulation of myeloid cell } \\
\text { differentiation (GO:0045638) }\end{array}$ & 4 & 9.56 & $1.02 \mathrm{E}-03$ \\
\hline Membrane depolarization (GO:0051899) & 3 & 9.4 & 4.70E-03 \\
\hline $\begin{array}{l}\text { Regulation of protein targeting } \\
\text { (GO:1903533) }\end{array}$ & 4 & 6.33 & 4.26E-03 \\
\hline $\begin{array}{l}\text { Negative regulation of hemopoiesis } \\
\text { (GO:1903707) }\end{array}$ & 4 & 5.75 & $5.90 \mathrm{E}-03$ \\
\hline $\begin{array}{l}\text { Regulation of cell morphogenesis } \\
\text { involved in differentiation (GO:0010769) }\end{array}$ & 6 & 4.55 & 2.44E-03 \\
\hline $\begin{array}{l}\text { Regulation of mitochondrion } \\
\text { organization (GO:0010821) }\end{array}$ & 5 & 4.49 & 5.87E-03 \\
\hline $\begin{array}{l}\text { Regulation of neuron projection } \\
\text { development (GO:0010975) }\end{array}$ & 8 & 4.27 & 7.09E-04 \\
\hline $\begin{array}{l}\text { Regulation of intracellular transport } \\
\text { (GO:0032386) }\end{array}$ & 7 & 3.55 & 4.16E-03 \\
\hline $\begin{array}{l}\text { Regulation of cell morphogenesis } \\
\text { (GO:0022604) }\end{array}$ & 8 & 3.33 & $3.28 \mathrm{E}-03$ \\
\hline $\begin{array}{l}\text { Regulation of neuron differentiation } \\
\text { (GO:0045664) }\end{array}$ & 9 & 3.32 & 1.86E-03 \\
\hline $\begin{array}{l}\text { Positive regulation of transport } \\
\text { (GO:0051050) }\end{array}$ & 14 & 2.92 & 3.81E-04 \\
\hline $\begin{array}{l}\text { Regulation of plasma membrane } \\
\text { bounded cell projection organization } \\
\text { (GO:0120035) }\end{array}$ & 8 & 2.86 & 7.79E-03 \\
\hline $\begin{array}{l}\text { Regulation of neurogenesis } \\
\text { (GO:0050767) }\end{array}$ & 9 & 2.68 & $7.28 \mathrm{E}-03$ \\
\hline $\begin{array}{l}\text { Regulation of nervous system } \\
\text { development (GO:0051960) }\end{array}$ & 10 & 2.55 & $6.61 \mathrm{E}-03$ \\
\hline Regulation of transport (GO:0051049) & 20 & 2.08 & $2.13 \mathrm{E}-03$ \\
\hline $\begin{array}{l}\text { Cell surface receptor signaling } \\
\text { pathway (GO:0007166) }\end{array}$ & 20 & 1.87 & $6.52 \mathrm{E}-03$ \\
\hline $\begin{array}{l}\text { Regulation of localization } \\
\text { (GO:0032879) }\end{array}$ & 25 & 1.74 & $7.58 \mathrm{E}-03$ \\
\hline \multicolumn{4}{|l|}{ Sex } \\
\hline $\begin{array}{l}\text { Histone H3-K27 demethylation } \\
\text { (GO:0071557) }\end{array}$ & 2 & 55.66 & $1.04 \mathrm{E}-03$ \\
\hline Kinetochore assembly (GO:0051382) & 3 & 52.18 & $5.64 \mathrm{E}-05$ \\
\hline $\begin{array}{l}\text { Positive regulation of sodium ion } \\
\text { transmembrane transporter activity } \\
\text { (GO:2000651) }\end{array}$ & 2 & 39.76 & $1.76 \mathrm{E}-03$ \\
\hline Kinetochore organization (GO:0051383) & 3 & 34.79 & $1.52 \mathrm{E}-04$ \\
\hline $\begin{array}{l}\text { Positive regulation of glycoprotein } \\
\text { biosynthetic process (GO:0010560) }\end{array}$ & 3 & 34.79 & $1.52 \mathrm{E}-04$ \\
\hline Regulation of skeletal muscle & 2 & 34.79 & $2.19 \mathrm{E}-03$ \\
\hline
\end{tabular}

Table 1 Enrichment analysis showing 20 most overrepresented ${ }^{\top}$ Biological Process for differentially expressed genes ${ }^{2}$ for the effects of diet and sex in the muscle tissue (Continued)

\begin{tabular}{|c|c|c|c|}
\hline Biological Process & \# genes & $\mathrm{FE}$ & $P$-value \\
\hline \multicolumn{4}{|l|}{ contraction (GO:0014819) } \\
\hline $\begin{array}{l}\text { Positive regulation of glycoprotein } \\
\text { metabolic process (GO:1903020) }\end{array}$ & 3 & 29.82 & 2.25E-04 \\
\hline $\begin{array}{l}\text { Centromere complex assembly } \\
\text { (GO:0034508) }\end{array}$ & 3 & 21.97 & 4.97E-04 \\
\hline $\begin{array}{l}\text { Establishment of melanosome } \\
\text { localization (GO:0032401) }\end{array}$ & 3 & 20.87 & $5.68 \mathrm{E}-04$ \\
\hline $\begin{array}{l}\text { Establishment of pigment } \\
\text { granule localization (GO:0051905) }\end{array}$ & 3 & 19.88 & $6.46 \mathrm{E}-04$ \\
\hline $\begin{array}{l}\text { Melanosome localization } \\
\text { (GO:0032400) }\end{array}$ & 3 & 19.88 & $6.46 \mathrm{E}-04$ \\
\hline $\begin{array}{l}\text { Pigment granule localization } \\
\text { (GO:0051875) }\end{array}$ & 3 & 18.98 & 7.30E-04 \\
\hline $\begin{array}{l}\text { ATP hydrolysis coupled } \\
\text { transmembrane transport } \\
\text { (GO:0090662) }\end{array}$ & 3 & 16.06 & $1.14 \mathrm{E}-03$ \\
\hline $\begin{array}{l}\text { ATP hydrolysis coupled proton } \\
\text { transport (GO:0015991) }\end{array}$ & 3 & 16.06 & $1.14 \mathrm{E}-03$ \\
\hline $\begin{array}{l}\text { Energy coupled proton transmembrane } \\
\text { transport, against electrochemical } \\
\text { gradient (GO:0015988) }\end{array}$ & 3 & 14.91 & $1.38 \mathrm{E}-03$ \\
\hline $\begin{array}{l}\text { Regulation of glucose metabolic } \\
\text { process (GO:0010906) }\end{array}$ & 5 & 9.53 & 2.41E-04 \\
\hline $\begin{array}{l}\text { Regulation of cellular carbohydrate } \\
\text { metabolic process (GO:0010675) }\end{array}$ & 5 & 7.65 & $6.29 \mathrm{E}-04$ \\
\hline $\begin{array}{l}\text { Regulation of carbohydrate metabolic } \\
\text { process (GO:0006109) }\end{array}$ & 5 & 6.5 & $1.26 \mathrm{E}-03$ \\
\hline Chromosome organization (GO:0051276) & 17 & 2.59 & 3.56E-04 \\
\hline $\begin{array}{l}\text { Cellular macromolecular complex } \\
\text { assembly (GO:0034622) }\end{array}$ & 14 & 2.57 & $1.32 \mathrm{E}-03$ \\
\hline
\end{tabular}

mid-gestation increases the number of fast (type II) muscle fibers, which generate energy through glycolytic pathways, as a compensatory process due to limited energy availability for muscle development. Mitochondrial oxidative phosphorylation is the primary pathway to produce energy for metabolic activities, which generates more adenosine triphosphate than glycolysis [41]; however, lack of energy can decrease the number of fast fibers [40], reducing the efficiency of energy production and, consequently, of metabolic activities. In accordance, Byrne et al. [42] suggested that caloric restriction may increase metabolism of amino acids to glucose via gluconeogenesis after finding increased gene expression levels associated with energy metabolism. Moreover, Peñagaricano et al. [9] showed that the maternal source of energy may affect gene expression in the muscle of sheep. These authors observed that dams fed a corn-based diet had greater expression of genes associated with embryonic 


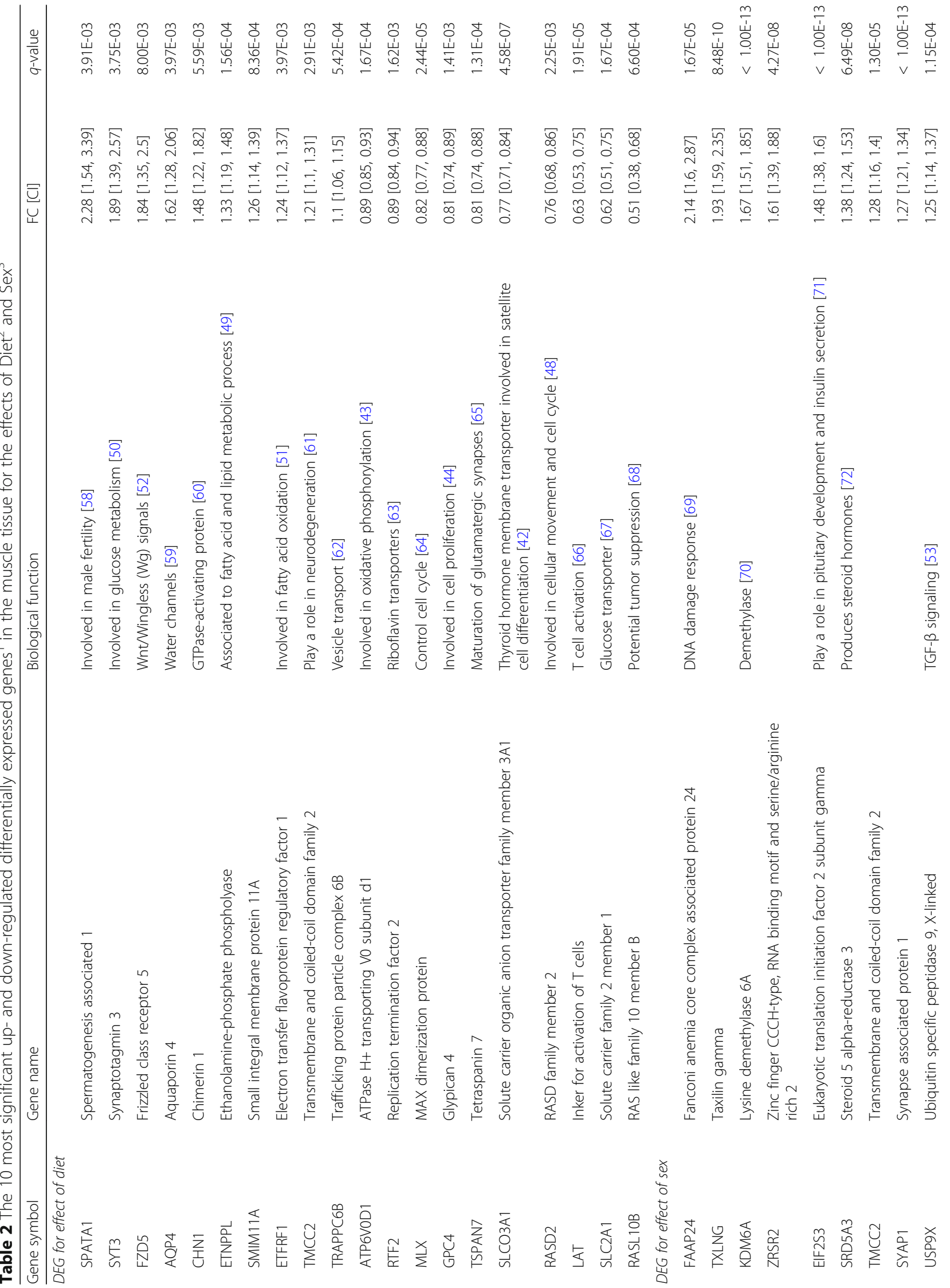




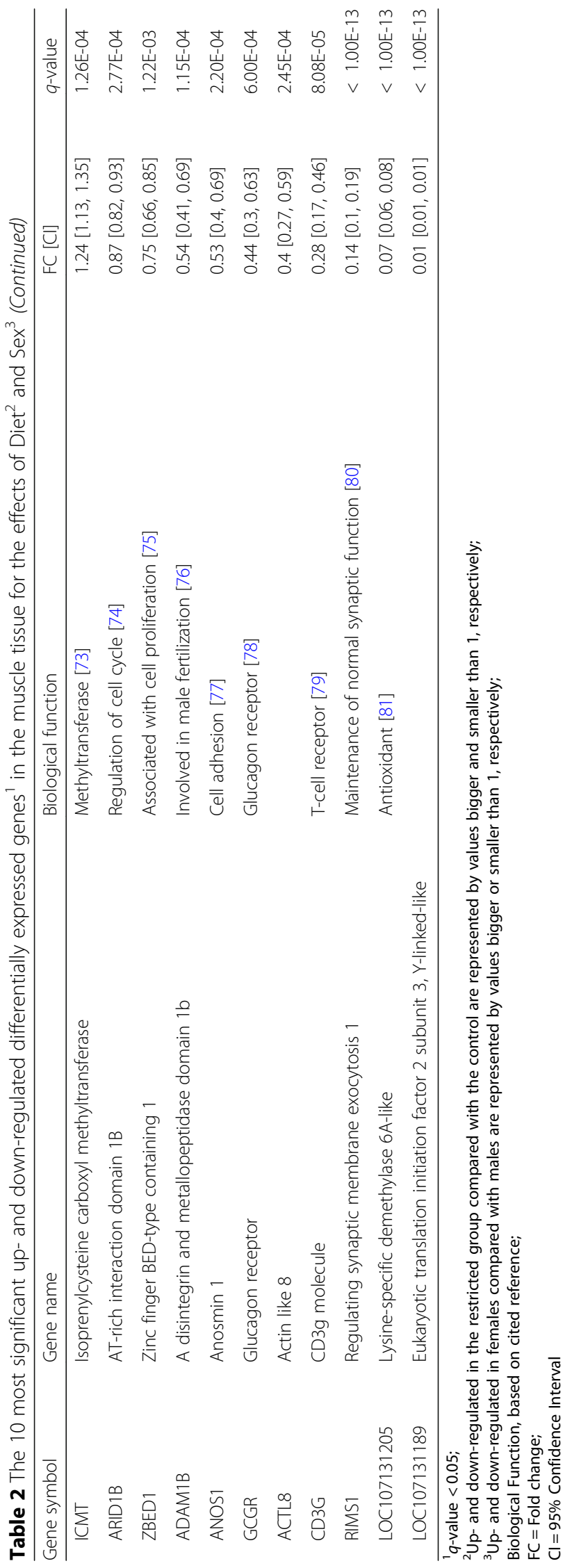


and fetal development, skeletal muscle, tissue differentiation, muscle myosin complex and sarcomere organization, than dams fed alfalfa haylage and distillers grains. These results indicate that the energy-restricted diet may be impairing the development of muscle tissue as well as altering the energy metabolism in the offspring. In addition, Yang et al. [39] reported the gene GP4 being less expressed due to hypermethylation in Chinese pigs, which are known for having less lean muscle mass and low growth rate, suggesting that the low expression may be occurring due to epigenetic modifications. The down-regulation of RASD2 in the REST may also indicate that the maternal energy restriction alters the proliferation capacity of the satellite cells, controlling the skeletal muscle hypertrophy. Raja et al. [43] have shown that energy restriction during gestation alters temporal expression of myogenic regulatory factors in satellite cells impairing the fusion of cells isolated from 3-month old lambs. Therefore, alterations in maternal nutrition during pregnancy may lead to negative effects on postnatal myogenesis.

In contrast, the REST showed a higher expression of genes related to fatty acid and glucose metabolism, such as ETNPPL, associated to fatty acid and to lipid metabolic process [44]; SYT3, involved in glucose metabolism [45]; and ETFRF1, involved in fatty acid oxidation [46]. SYT3 has been shown to be up-regulated in a mutated mice presenting a lean phenotype, resistance to high fat diet, and insulin resistance [45]. This finding suggests that the REST presents an impaired glucose metabolism compared with the CTRL group, which may be influencing the increase in expression of genes associated with fatty acid metabolism (ETNPPL and ETFRF1). In addition, the overexpression of FZD5 in the REST may indicate an disruption on Wnt signaling, which is related to diverse functions in developmental processes, including glucose metabolism [47]. These findings suggest that energy restriction during late pregnancy affects glucose metabolism and enhances fatty acid metabolism.

The 10 most significant DEG for the effect of sex are summarized in Table 2. The most significant up-regulated gene in males was RIMS1 with a FC of 0.14 [0.1, 0.19] $(q$-value $=<1.00 \mathrm{E}-13)$, and in females was SYAP1 with a FC of $1.27[1.21,1.34]$ ( $q$-value $=<1.00 \mathrm{E}-13)$. The most extreme FC was observed for LOC107131189 with 0.01 $[0.01,0.01](q$-value $=<1.00 \mathrm{E}-13)$. From the $10 \mathrm{most}$ DEG for the effect of sex, in accordance with the enrichment analyses, we identified genes associated with glucose metabolism, such as GCGR (up-regulated in males) and EIF2S3 (up-regulated in females) and chromatin biology and epigenetic modifications, such as KDM6A and ICMT up-regulated in females compared with males. In accordance, glucose metabolism had been thought to differ between male and female embryos [48]. In addition, Alvarez et al. [49] found higher transcriptional expression in females compared with males. We propose that the X-linked gene inactivation in females may occur as a result of an imprinting mechanism leading to a total or partial maternal allele transcriptional repression [49], which can generate an up-regulation of genes in females compared with males (Fig. 2). These results suggest that the different gene expression levels occurs due to difference in sex chromosome dosage. The complete list of DEG ( $q$-value $<0.05)$ for the effects of diet, sex, and interaction diet-by-sex is provided in Additional file 2.

\section{Enrichment analysis in the blood}

The enrichment analyses for the different sets of DEG in the blood are presented in Table 3. Results based on diet showed general metabolic functions $(P<0.05)$, such as translation (GO:0006412), rRNA metabolic process (GO:0016072), and biosynthetic process (GO:0009058) in addition to carbohydrate metabolism such as regulation of carbohydrate metabolic process (GO:0006109) and glycogen metabolic process (GO:0005977). In contrast, for results based on biologically relevant contrasts, there was an overrepresentation of biological processes related to immune response for the effect of vaccination, such as immune system process (GO:0002376), regulation of response to stimulus (GO:0048583), and positive regulation of response to stimulus (GO:0048584), in addition to other general biological processes, such as localization (GO:0051179), and transport (GO:0006810). For the effect of weaning, we found GO terms associated with response to stress and immune system, i.e. cellular response to DNA damage stimulus (GO:0006974), response to stress (GO:0006950), regulation of lymphocyte activation (GO:0051249) and response to interleukin-4 (GO:0070670). These include cellular response to DNA damage stimulus (GO:0006974), response to stress (GO:0006950), regulation of lymphocyte activation (GO:0051249), response to interleukin-4 (GO:0070670) and immune system process (GO:0002376), suggesting that the maternal nutrition during pregnancy influenced the response of the offspring to the immune challenge after weaning and vaccination. It has been shown that the immune challenge may elicit an acute phase response which decreases feed intake and increases protein demand to support the immune system $[12,13]$ leading to compromised growth. The energy-restricted diet may be impairing the animal's response in this phase, since the energy metabolism might be compromised and less efficient for synthesizing protein for the immune system. Additional enrichment analysis results $(P<0.05)$ including under and overrepresented molecular function GO terms for the effects of diet and time can be seen in Additional file 3. 
Table 3 Enrichment analysis showing 20 most overrepresented ${ }^{1}$ Biological Process for differentially expressed genes ${ }^{2}$ for diet and biologically relevant contrasts in the blood tissue

\begin{tabular}{|c|c|c|c|}
\hline Biological Process & \# genes & $\mathrm{FE}$ & $P$-value \\
\hline \multicolumn{4}{|l|}{ Diet } \\
\hline $\begin{array}{l}\text { Regulation of carbohydrate } \\
\text { metabolic process (GO:0006109) }\end{array}$ & 3 & 6.54 & $1.37 \mathrm{E}-02$ \\
\hline Translation (GO:0006412) & 22 & 4.3 & $3.42 \mathrm{E}-08$ \\
\hline $\begin{array}{l}\text { Glycogen metabolic process } \\
\text { (GO:0005977) }\end{array}$ & 3 & 4.03 & 4.38E-02 \\
\hline $\begin{array}{l}\text { Transcription initiation from RNA } \\
\text { polymerase II promoter (GO:0006367) }\end{array}$ & 4 & 3.81 & 2.47E-02 \\
\hline rRNA metabolic process (GO:0016072) & 10 & 3.77 & $5.20 \mathrm{E}-04$ \\
\hline Protein targeting (GO:0006605) & 8 & 2.3 & 2.73E-02 \\
\hline $\begin{array}{l}\text { Cellular component biogenesis } \\
\text { (GO:0044085) }\end{array}$ & 36 & 2.08 & $6.01 \mathrm{E}-05$ \\
\hline Protein localization (GO:0008104) & 18 & 1.72 & 2.71E-02 \\
\hline Organelle organization (GO:0006996) & 39 & 1.51 & $1.36 \mathrm{E}-02$ \\
\hline Biosynthetic process (GO:0009058) & 55 & 1.49 & 4.07E-03 \\
\hline $\begin{array}{l}\text { Cellular component organization or } \\
\text { biogenesis (GO:0071840) }\end{array}$ & 65 & 1.48 & $1.68 \mathrm{E}-03$ \\
\hline $\begin{array}{l}\text { Cellular component organization } \\
\text { (GO:0016043) }\end{array}$ & 54 & 1.32 & $3.77 \mathrm{E}-02$ \\
\hline Primary metabolic process (GO:0044238) & 119 & 1.19 & $3.26 \mathrm{E}-02$ \\
\hline \multicolumn{4}{|l|}{ Weaning } \\
\hline Translation (GO:0006412) & 101 & 5.84 & $6.58 \mathrm{E}-42$ \\
\hline Peptide biosynthetic process (GO:0043043) & 101 & 5.64 & $8.81 \mathrm{E}-41$ \\
\hline Amide biosynthetic process (GO:0043604) & 103 & 5.09 & $3.67 E-38$ \\
\hline Peptide metabolic process (GO:0006518) & 103 & 4.8 & $3.40 \mathrm{E}-36$ \\
\hline $\begin{array}{l}\text { Cellular amide metabolic process } \\
\text { (GO:0043603) }\end{array}$ & 106 & 4.08 & $7.70 \mathrm{E}-32$ \\
\hline Ribosome biogenesis (GO:0042254) & 37 & 3.65 & $1.55 \mathrm{E}-10$ \\
\hline $\begin{array}{l}\text { Organonitrogen compound biosynthetic } \\
\text { process (GO:1901566) }\end{array}$ & 125 & 2.68 & $4.22 \mathrm{E}-22$ \\
\hline $\begin{array}{l}\text { Cellular macromolecule biosynthetic } \\
\text { process (GO:0034645) }\end{array}$ & 181 & 2.21 & 4.73E-23 \\
\hline $\begin{array}{l}\text { Macromolecule biosynthetic process } \\
\text { (GO:0009059) }\end{array}$ & 181 & 2.17 & $1.99 \mathrm{E}-22$ \\
\hline $\begin{array}{l}\text { Cellular nitrogen compound } \\
\text { biosynthetic process (GO:0044271) }\end{array}$ & 165 & 2.11 & 4.11E-19 \\
\hline Gene expression (GO:0010467) & 168 & 1.85 & $3.42 \mathrm{E}-14$ \\
\hline $\begin{array}{l}\text { Cellular protein metabolic process } \\
\text { (GO:0044267) }\end{array}$ & 213 & 1.84 & $3.63 \mathrm{E}-18$ \\
\hline $\begin{array}{l}\text { Organic substance biosynthetic } \\
\text { process (GO:1901576) }\end{array}$ & 203 & 1.8 & 2.37E-16 \\
\hline $\begin{array}{l}\text { Cellular biosynthetic process } \\
\text { (GO:0044249) }\end{array}$ & 198 & 1.8 & $9.94 \mathrm{E}-16$ \\
\hline Biosynthetic process (GO:0009058) & 204 & 1.76 & $1.74 \mathrm{E}-15$ \\
\hline Organelle organization (GO:0006996) & 178 & 1.74 & $6.55 \mathrm{E}-13$ \\
\hline $\begin{array}{l}\text { Cellular nitrogen compound } \\
\text { metabolic process (GO:0034641) }\end{array}$ & 232 & 1.7 & $3.41 \mathrm{E}-16$ \\
\hline Protein metabolic process & 232 & 1.64 & $1.84 \mathrm{E}-14$ \\
\hline
\end{tabular}

Table 3 Enrichment analysis showing 20 most overrepresented ${ }^{\top}$ Biological Process for differentially expressed genes ${ }^{2}$ for diet and biologically relevant contrasts in the blood tissue (Continued)

\begin{tabular}{lccc}
\hline Biological Process & \# genes & FE & $P$-value \\
\hline $\begin{array}{l}\text { (GO:0019538) } \\
\begin{array}{l}\text { Cellular macromolecule metabolic } \\
\text { process (GO:0044260) }\end{array}\end{array}$ & 293 & 1.62 & $1.85 \mathrm{E}-18$ \\
$\begin{array}{l}\text { Cellular component organization } \\
\text { or biogenesis (GO:0071840) }\end{array}$ & 252 & 1.52 & $2.74 \mathrm{E}-12$ \\
Macromolecule metabolic process & 320 & 1.42 & $2.33 \mathrm{E}-12$
\end{tabular}
(GO:0043170)

Vaccination

Myeloid leukocyte activation

$5.47 \quad 1.93 \mathrm{E}-04$ (GO:0002274)

Transition metal ion transport (GO:0000041)

9

Positive regulation of response to external stimulus (GO:0032103)

Positive regulation of GTPase activity (GO:0043547)

Regulation of GTPase activity (GO:0043087)

Positive regulation of hydrolase activity (GO:0051345)

Regulation of response to external stimulus (GO:0032101)

Cellular homeostasis (GO:0019725)

Immune system process

(GO:0002376)

Regulation of hydrolase activity (GO:0051336)

Positive regulation of response to stimulus (GO:0048584)

Cellular response to organic substance (GO:0071310)

Cellular response to chemical stimulus (GO:0070887)

Localization (GO:0051179)

Establishment of localization (GO:0051234)

Transport (GO:0006810)

Regulation of response to stimulus (GO:0048583)

Cell differentiation (GO:0030154)

Regulation of signal transduction (GO:0009966)

Regulation of signaling (GO:0023051)

Developmental process (GO:0032502)

${ }^{1} P$-value $<0.05$;

${ }^{2} q$-value $<0.05$;

$\mathrm{FE}=$ fold enrichment 


\section{Major DEG in blood tissue}

The effect of the interaction diet-by-time was analyzed based on biologically relevant contrasts. The 10 most significant DEG for the effect of interaction diet-by-weaning and diet-by-vaccination are summarized in Table 4. Of these, the most significant gene for the effect of interaction diet-by-weaning was USF3 ( $q$-value $=1.13 \mathrm{E}-04)$ and for the effect of diet-by-vaccination was LOC104968634 $(q$-value $=6.62 \mathrm{E}-04)$. In addition, we found differential expression in genes related to immune system and response to stress, such as $K L R K 1$, which stimulates the natural killer (NK) cells [50] and INO8OD [51], involved in oxidation-reduction activity. KLRK1 was down-regulated and INO8OD was up-regulated in the REST after weaning (Fig. 3). In accordance with the results in the muscle tissue for the effect of energy-restricted diet, we hypothesized that the REST triggered a more pronounced stress process than the CRTL during the acute response phase. When we looked at the effect of interaction diet-by-vaccination, we found genes involved in the immune response being down-regulated in the REST after vaccination (Fig. 4), such as $O A S L$, which is involved in response to viral infections [52]; KLRF1, which is expressed on nearly all NK cells and stimulates their cytotoxicity and cytokine release [50]; and LOC104968634, an antimicrobial peptide stimulating NK cells cytoxicity. These findings suggest that the CRTL responded better to the immune challenge which may be due to a better development of the immune system during prenatal phase. Also, these data are in agreement with Moriel et al. [18], who using part of the same data used in this study, showed that $70 \%$ of energy restriction during the last 40 days of gestation decreased post-weaning vaccination-induced humoral immunity, inflammatory, and physiological stress responses in calves. Our results support the hypothesis that maternal energy restriction during pregnancy can alter gene expression in

Table 410 most differentially Expressed Genes ${ }^{1}$ in the blood for biologically relevant contrasts

\begin{tabular}{|c|c|c|c|}
\hline Gene symbol & Gene name & Biological function & $q$-value \\
\hline \multicolumn{4}{|c|}{$D E G$ for effect of interaction diet-by-weaning } \\
\hline USF3 & Upstream transcription factor family member 3 & Regulates Major Histocompatibility Complex [82] & 1.13E-04 \\
\hline STARD6 & StAR related lipid transfer domain containing 6 & Structure and lipid transport mechanism [83] & 3.10E-04 \\
\hline PHC3 & Polyhomeotic homolog 3 & & 3.17E-04 \\
\hline BRMSTL & Breast cancer metastasis-suppressor 1 like & Metastasis suppression [84] & 4.87E-04 \\
\hline MPV17L & $\begin{array}{l}\text { MPV17L mitochondrial inner membrane } \\
\text { protein like }\end{array}$ & $\begin{array}{l}\text { Up- or down-regulation of the genes of } \\
\text { antioxidant enzymes [85] }\end{array}$ & 4.92E-04 \\
\hline NBEAL1 & Neurobeachin like 1 & $\begin{array}{l}\text { Vesicle trafficking, membrane dynamics and } \\
\text { receptor signaling [86] }\end{array}$ & 7.31E-04 \\
\hline C5H12orf4 & $\begin{array}{l}\text { Chromosome } 5 \text { open reading frame, human } \\
\text { C12orf4 }\end{array}$ & & 7.59E-04 \\
\hline INO80D & INO80 complex subunit D & DNA damage responses [51] & 8.00E-04 \\
\hline TIGD3 & Tigger transposable element derived 3 & & 8.94E-04 \\
\hline KLRK1 & Killer cell lectin like receptor F1 & $\begin{array}{l}\text { Stimulates natural killer (NK) cells cytoxicity and } \\
\text { cytokine release [50] }\end{array}$ & $9.05 \mathrm{E}-04$ \\
\hline \multicolumn{4}{|c|}{ DEG for effect of interaction diet-by-vaccination } \\
\hline LOC104968634 & Antimicrobial peptide NK-lysin-like & Antimicrobial activity [87] & $6.62 \mathrm{E}-04$ \\
\hline GPR161 & G protein-coupled receptor 161 & Involved in neural tube development [88] & 2.13E-03 \\
\hline KLRF1 & Killer cell lectin like receptor F1 & $\begin{array}{l}\text { Stimulates NK cells cytoxicity and cytokine } \\
\text { release [50] }\end{array}$ & $2.20 \mathrm{E}-03$ \\
\hline $\mathrm{PMCH}$ & Pro-melanin concentrating hormone & Feed intake control [89] & $2.81 \mathrm{E}-03$ \\
\hline PIK3C2G & $\begin{array}{l}\text { Phosphatidylinositol-4-phosphate 3-kinase } \\
\text { catalytic subunit type } 2 \text { gamma }\end{array}$ & Control cell proliferation [90] & $3.15 \mathrm{E}-03$ \\
\hline KRT24 & Keratin 24 & & 3.64E-03 \\
\hline PRRT3 & Proline rich transmembrane protein 3 & Protein binding [91] & 3.74E-03 \\
\hline QRICH2 & Glutamine rich 2 & Cupper regulation [92] & $4.18 \mathrm{E}-03$ \\
\hline HIST2H2AB & Histone cluster 2 H2A family member B & $\begin{array}{l}\text { Play a central role in transcription regulation, DNA } \\
\text { repair and DNA replication [93] }\end{array}$ & $4.22 \mathrm{E}-03$ \\
\hline OASL & 2'-5'-oligoadenylate synthetase like & Response to viral infections [52] & 4.73E-03 \\
\hline
\end{tabular}

${ }^{1} P$-value $<0.05$ for significant $(q$-value $<0.05$ ) effects of diet-time interaction; Biological Function, based on cited reference 


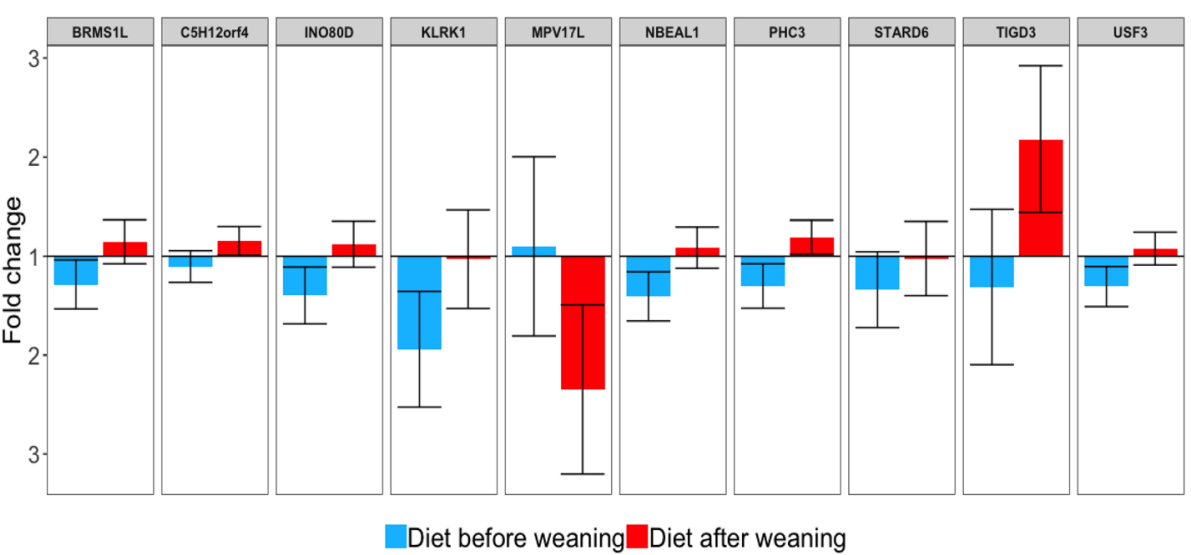

Fig. 3 The 10 most differentially expressed genes ( $q$-value $<0.05)$ showing interaction between the effects of diet and weaning in the blood tissue. Bars represent the fold change $(F C)$ for the effect $(P$-value $<0.05)$ of diet before (blue) and after (red) weaning, with error bars representing the $95 \%$ confidence interval. Fold change values equal to 1 represent same expression between the diets (control and restricted). Fold change values on the top and bottom halves represent up-regulated DEG in the restricted and control groups, respectively. The name and function of these genes are summarized on Table 4

the offspring associated with immune response which may reflect on the productive performance of the animal. The complete list of DEG ( $q$-value $<0.05$ ) for the effects of diet, time, and interaction diet-by-time is provided in Additional file 4.

\section{Partial correlation network in the muscle and blood}

The partial correlation network including all (Fig. 5a) and the 20 (Fig. $5 \mathrm{~b})$ most DEG ( $q$-value $<0.05)$ is depicted in Fig. 5. From the gene network containing all DEG, it seems there are more negative correlations than positive and there is a high correlation between the down- and up-regulated DEG in the muscle. From the network containing the 20 most DEG, the genes with strongest positive correlations were ETNPPL, which is involved in the fatty acid metabolism and is being strongly positively correlated with GPC4 and $R A S L 10 B$, and negative correlated with $M L X$ and TRAPPC6. The result from the partial correlation network containing all DEG linking muscle and blood (Fig. 6a) showed high negative connectivity between the DEG in the muscle and fewer between muscle and blood. Then, looking at the gene network containing the most 10 DEG in muscle associated with the 10 DEG in blood (Fig. 6b), we can see a higher negative correlation with each tissue but a higher positive correlation between muscle and blood. The gene with higher positive connectivity was GOT1L1, which has been associated with immune response and is been used as cell indicator of stress in cattle semen [53].

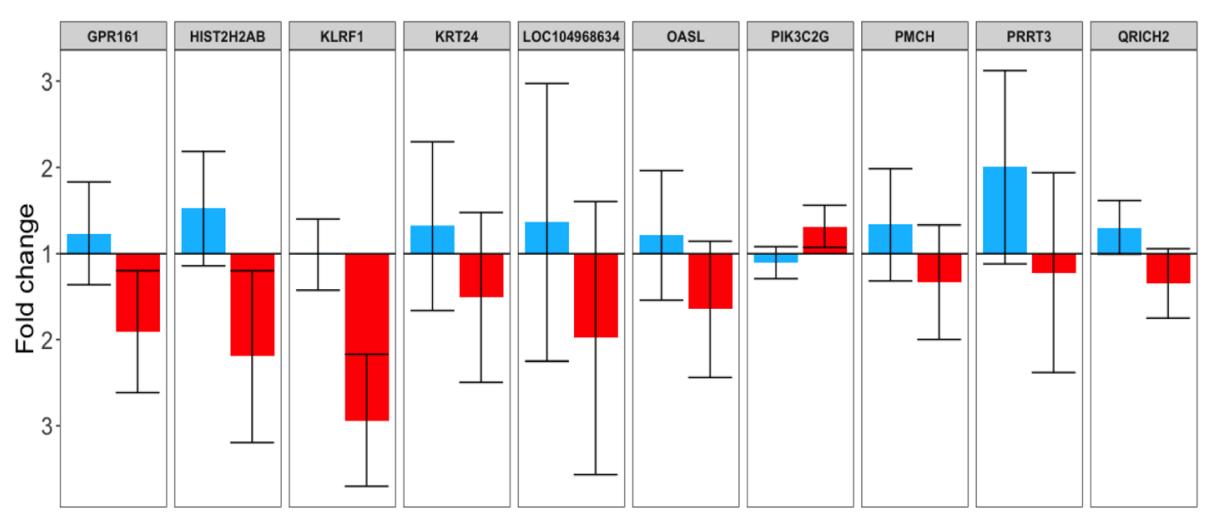

Diet before vaccination Diet after vaccination

Fig. 4 The 10 most differentially expressed genes ( $q$-value $<0.05)$ showing interaction between the effects of diet and vaccination in the blood tissue. Bars represent the fold change (FC) for the effect $(P$-value $<0.05)$ of diet before (blue) and after (red) vaccination, with error bars representing the $95 \%$ confidence interval. Fold change values equal to 1 represent same expression between the diets (control and restricted). Fold change values on the top and bottom halves represent up-regulated DEG in the restricted and control groups, respectively. The name and function of these genes are summarized on Table 4 


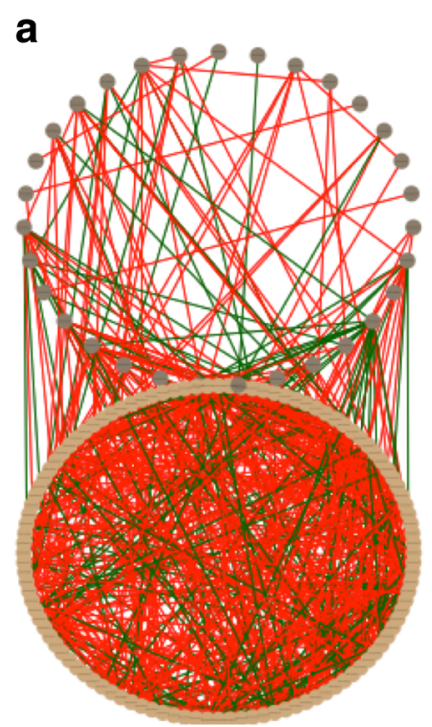

b

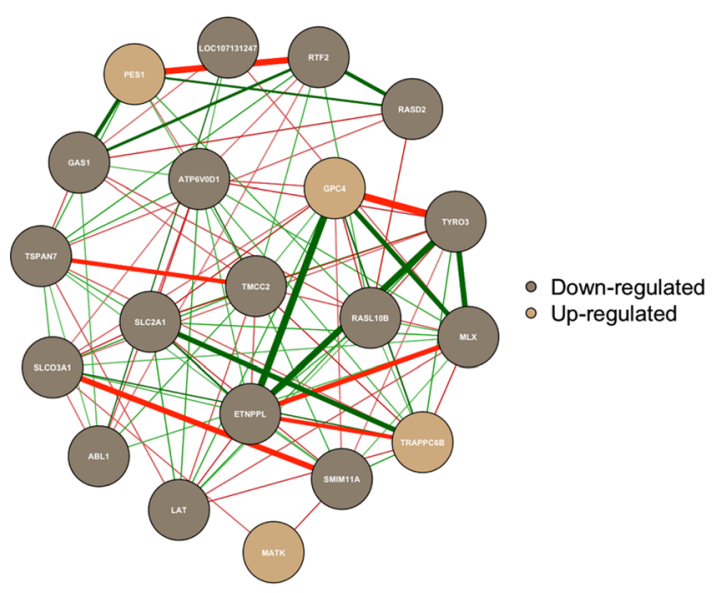

Fig. 5 Partial correlation networks for all (a) and the 20 (b) most differentially expressed genes (DEG; $q$-value $<0.05$ ) for the effect of diet in muscle. Brown and Beige nodes represent down- and up-regulated DEG in the restricted, respectively. Red and green lines represent negative and positive correlation (correlation $>|0.8|$ ), respectively

Among the DEG in both blood and muscle (SPAG17, VAT1, CABLES1, SLC20A2, ILF3, QDPR, and LOC10 7131247), most of them were down-regulated in the muscle and up-regulated in the blood, except for SPAG17 and LOC107131247 which were down-regulated in both. Among the genes down-regulated in the muscle and up-regulated in the blood, some of them are associated with immune system and stress process, i.e. ILF3 [54], QDPR [55], CABLES1 [56], and LOC107131247 [57]. CA$B L E S 1$ is a glucocorticoid-activated cell cycle regulator, and glucocorticoids are known to be involved in several functions including enhanced response to stress and decreased protein synthesis in skeletal muscle. Therefore, the DEG expressed in both blood and muscle tissue may be playing different roles in each of the tissues.

\section{Conclusion}

This study shows that reducing dietary energy for pregnant cows by $30 \%$ during the last 40 days of gestation impacts the transcriptomic profile in the skeletal muscle and blood tissues in the offspring. Maternal energy restriction reduced the expression of genes in the skeletal muscle tissue and increased gene expression in the blood tissue. Specifically, we observed a reduction of genes associated
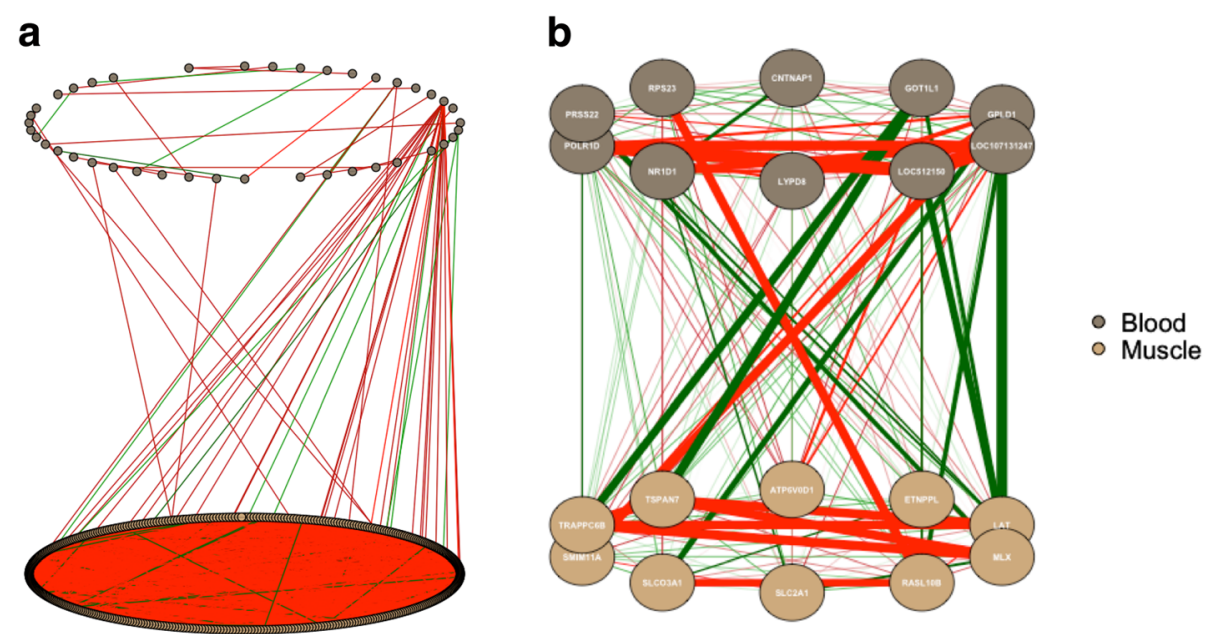

Fig. 6 Partial correlation networks for all (a) and the 10 most differentially expressed genes (DEG; $q$-value $<0.05$ ) for the effect of diet in muscle associated with the 10 most DEG in blood tissue (b). Brown and Beige nodes represent overexpressed DEG in the blood and muscle, respectively. Red and green lines represent negative and positive correlation (correlation $>|0.8|$ ), respectively 
with energy metabolism and muscle development in the skeletal muscle tissue. In the blood tissue, there was a decrease in the expression of genes associated with immune response and stress processes in the REST after weaning and vaccination. Also, we found that the DEG in the muscle and blood showed a connectivity between them, enhancing the importance of the immune system as a target tissue for the effect of maternal energy restriction during late pregnancy. These finding suggest that energy restriction during late pregnancy may trigger a more pronounced stress response in the offspring that may impair the muscle tissue and immune system development.

\section{Additional files}

Additional file 1: Gene set enrichment analysis output for muscle. Excel file with term ontologies from the enrichment analysis. The tabs correspond to each effect of diet and sex in the muscle tissue. The columns represent: (1) GO terms, (2) number of genes associated with the GO term in the reference genome, (3) number of genes associated with the $\mathrm{GO}$ term in the list of differentially expressed genes (DEG), (4) number of genes associated with the $\mathrm{GO}$ term associated expected in the in the list of DEG, (5) signal representing over-representation (+) or under-representation (-), (6) fold enrichment, and (7) P-value. (XLSX $44 \mathrm{~kb}$ )

Additional file 2: Differentially expressed genes in muscle. Excel file with all differentially expressed genes (DEG; $q$-value $<0.05$ ). The tabs correspond to each effect of diet, sex and diet-by-sex in the muscle tissue. The columns represent: (1) Ensembl gene ID, (2) HGNC gene symbol, (3) q-values (FDR corrected $P$-values), (4) fold change, values between 0 and 1 being down-regulated and values bigger than 1 representing the up-regulated in the REST, and (5) standard errors of the fold change. (XLSX $215 \mathrm{~kb}$ )

Additional file 3: Gene set enrichment analysis output for blood. Excel file with term ontologies from the enrichment analysis. The tabs correspond to each effect of diet and time in the blood tissue. The columns represent: (1) GO terms, (2) number of genes associated with the GO term in the reference genome, (3) number of genes associated with the GO term in the list of differentially expressed genes (DEG), (4) number of genes associated with the GO term associated expected in the in the list of DEG, (5) signal representing over-representation (+) or under-representation (-), (6) fold enrichment, and (7) P-value. (XLSX $15 \mathrm{~kb}$ )

Additional file 4: Differentially expressed genes in the blood. Excel file with all differentially expressed genes (DEG; $q$-value $<0.05$ ). The tabs correspond to each effect of diet, time and diet-by-time in the blood tissue. The columns represent: (1) Ensembl gene ID, (2) HGNC gene symbol, (3) q-values (FDR corrected $P$-values), (4) fold change, values between 0 and 1 being down-regulated and values bigger than 1 representing the up-regulated in the REST, and (5) standard errors of the fold change. (XLSX $102 \mathrm{~kb}$ )

\section{Abbreviations}

AIC: Akaike information criterion; ATPGVOD1: ATPase H+ transporting VO subunit d1; CABLES1: Cdk5 and Abl enzyme substrate 1; CTRL: control group; DEG: differentially expressed genes; DF: degree-of-freedom; DPW: days post weaning; EIF2S3: Eukaryotic translation initiation factor 2 subunit gamma; ETFRF1: Electron transfer flavoprotein regulatory factor 1; ETNPPL: Ethanolaminephosphate phospholyase; FC: fold change; FDR: false-discovery rate; FZD5: Frizzled class receptor 5; GCGR: Glucagon receptor; GO: gene ontology; GOT1L1: Glutamic-oxaloacetic transaminase 1 like 1; GPC4: Glypican 4; GTF2A1L: General transcription factor IIA subunit 1 like; ICMT: Isoprenylcysteine carboxyl methyltransferase; ILF3: Interleukin enhancer binding factor 3; INO80D: INO80 complex subunit D; KDM6A: Lysine demethylase 6A; KLRF1: Killer cell lectin like receptor F1; LOC104968634: Antimicrobial peptide NK-lysin-like; LOC107131189: Eukaryotic translation initiation factor 2 subunit 3, Y-linked-like; LOC107131247: Multidrug resistance-associated protein 4-like; LOC512150: Myeloidassociated differentiation marker-like; MATK: Megakaryocyte-associated tyrosine kinase; NK: natural killer; OASL: 2'-5'-oligoadenylate synthetase like; QDPR: Quinoid dihydropteridine reductase; RASD2: RASDfamily member 2; REST: energy-restricted group; RIMS1: Regulating synaptic membrane exocytosis 1; RIN: RNA integrity number; SLC20A2: Solute carrier family 20 member 2; SLCO3A1: Solute carrier organic anion transporter family member 3A1; SPAG17: Sperm associated antigen 17; SYAP1: Synapse associated protein 1; SYT3: Synaptotagmin 3; TMCC2: Transmembrane and coiled-coil domain family 2; TMM: Trimmed Mean of M-values; USF3: Upstream transcription factor family member 3; USP9X: Ubiquitin specific peptidase 9, X-linked; VAT1: Vesicle amine transport 1

\section{Funding}

Funding for this work was provided in part by Zoetis Animal Health, lowa State Agricultural Experiment Station, Mountain Research Station (Waynesville, NC) from the North Carolina Department of Agriculture, and the Hatch Program of the National Institute of Food and Agriculture, U.S. Department of Agriculture Support.

Availability of data and materials

The datasets generated and analyzed during the current study are available in the EMBL Nucleotide Sequence Database (ENA) repository, accession number: ERA1598646, https://www.ebi.ac.uk/ena.

Raw RNA-seq data and metadata could be available upon request.

\section{Author's contributions}

LPS: performed data analyses, interpreted results, and drafted manuscript; MN: assisted with bioinformatics and statistical analyses of the data, intellectually contributed with interpretation of the results, and drafted the manuscript; PM: designed and carried out animal trial, collected samples, and revised the manuscript while intellectually contributing with the content; JS: directed RNA extraction and sequencing, and revised the manuscript while intellectually contributing with the content; MA: directed RNA extractions, sample collection, and revised the manuscript while intellectually contributing with the content; MHP: designed the animal trial, assisted with sample collection, and revised the manuscript while intellectually contributing with the content; MSD: developed RNA-seq study, intellectually contributed with interpretation of the results, and drafted the manuscript; NVLS: developed RNA-seq study, data analyses, interpretation of results, and drafted manuscript. All authors read and approved the final version of the manuscript.

\section{Ethics approval and consent to participate}

All procedures used for data collection were in accordance with all animal welfare regulations and approved by the Institutional Animal Care and Use Committee of North Carolina State University (protocol number 15-014-A).

\section{Consent for publication}

Not applicable.

\section{Competing interests}

The authors declare that they have no competing interests.

\section{Publisher's Note}

Springer Nature remains neutral with regard to jurisdictional claims in published maps and institutional affiliations.

\section{Author details}

'Department of Animal Science, lowa State University, Ames 50011, USA. ${ }^{2}$ Department of Animal Science, North Carolina State University, Raleigh 27695, USA. ${ }^{3}$ Department of Statistics, Universidade Federal de Viçosa, Viçosa 36570-000, Brazil. ${ }^{4}$ Range Cattle Research and Education Center, University of Florida, Ona, Florida 33865, USA. ${ }^{5}$ Department of Animal Science, Universidade Federal de Viçosa, Viçosa 36570-000, Brazil. 'Instituto Nacional de Ciência e Tecnologia - Ciência Animal, Viçosa 36570-000, Brazil.

Received: 9 January 2018 Accepted: 19 September 2018

Published online: 25 September 2018

\section{References}

1. Duarte MS, Paulino PVR, Nascimento CS, Botelho ME, Martins TS, Filho SCV, Guimarães SEF, Serão NVL, Dodson MV, Du M, Gionbelli MP. Maternal overnutrition enhances mRNA expression of adipogenic markers and collagen deposition in skeletal muscle of beef cattle fetuses. J Anim Sci. 2014;92:3846-54. 
2. Larson DM, Martin JL, Adams DC, Funston RN. Winter grazing system and supplementation during late gestation influence performance of beef cows and steer progeny. J Anim Sci. 2009;87:1147-55.

3. He ZX, Wu DQ, Sun ZH, Tan ZL, Qiao JY, Ran T, Tang SX, Zhou CS, Han XF, Wang $M$, Kang $J H$, Beauchemin KA. Protein or energy restriction during late gestation alters fetal growth and visceral organ mass: an evidence of intrauterine programming in goats. Anim Reprod Sci. 2013;137:177-82.

4. Olson DP, Bull RC. Antibody responses in protein-energy restricted beef cows and their cold stressed progeny. Can J Vet Res. 1986;50:410-7.

5. McLoughlin KE, Nalpas NC, Rue-Albrecht K, Browne JA, Magee DA, Killick KE, Park SDE, Hokamp K, Meade KG, O'Farrelly C, Gormley E, Gordon SV, MacHugh DE. RNA-seq transcriptional profiling of peripheral blood leukocytes from cattle infected with Mycobacterium bovis. Front Immunol. 2014;5:1-19.

6. Fowden $A L, D$ a G, Forhead AJ. Intrauterine programming of physiological systems: causes and consequences. Physiology (Bethesda). 2006;21:29-37.

7. Yan X, Zhu M-J, Dodson MV, Du M. Developmental programming of fetal skeletal muscle and adipose tissue development. J genomics. 2013;1:29-38.

8. Loerch SC, Fluharty FL. Physiological changes and digestive capabilities of newly received feedlot cattle. J Anim Sci. 1999;77:1113-9.

9. Marques $\mathrm{AH}, \mathrm{O}^{\prime}$ Connor TG, Roth $\mathrm{C}$, Susser E, Bjørke-Monsen AL. The influence of maternal prenatal and early childhood nutrition and maternal prenatal stress on offspring immune system development and neurodevelopmental disorders. Front Neurosci. 2013;7:1-17.

10. Peñagaricano F, Wang $X$, Rosa GJ, Radunz AE, Khatib H. Maternal nutrition induces gene expression changes in fetal muscle and adipose tissues in sheep. BMC Genomics. 2014;15:1034.

11. O'Loughlin A, Lynn DJ, McGee M, Doyle S, McCabe M, Earley B. Transcriptomic analysis of the stress response to weaning at housing in bovine leukocytes using RNA-seq technology. BMC Genomics. 2012;13:250.

12. Cooke RF, Bohnert DW. Technical note: bovine acute-phase response after corticotrophin-release hormone challenge. J Anim Sci. 2011;89:252-7.

13. Arthington JD, Cooke RF, Maddock TD, Araujo DB, Moriel P, Dilorenzo N, Lamb GC. Effects of vaccination on the acute-phase protein response and measures of performance in growing beef calves1. J Anim Sci. 2013;91: 1831-7.

14. Jahoor F, Wykes L, Del Rosario M, Frazer M, Reeds PJ. Chronic protein undernutrition and an acute inflammatory stimulus elicit different protein kinetic responses in plasma but not in muscle of piglets. J Nutr. 1999;129:693-9.

15. Reeds $P$, Jahoor F. The amino acid requirements of disease. Clin Nutr. 2001; 20:15-22.

16. Duff GC, Galyean ML. Board-invited review: recent advances in management of highly stressed, newly received feedlot cattle. J Anim Sci. 2007:85:823-40.

17. National Research Council. Nutrient requirements of beef cattle. Natl Acad Press. 2000:232.

18. Moriel P, Piccolo MB, Artioli LFA, Marques RS, Poore MH, Cooke RF. Shortterm energy restriction during late gestation of beef cows decreases postweaning calf humoral immune response to vaccination. J Anim Sci. 2016;94:2542-52.

19. Artioli LFA, Moriel P, Poore MH, Marques RS, Cooke RF. Decreasing the frequency of energy supplementation from daily to three times weekly impairs growth and humoral immune response of preconditioning beef steers. J Anim Sci. 2015;93:5430-41.

20. Moriel P, Artioli LFA, Poore MH, Confer AW, Marques RS, Cooke RF. Increasing the metabolizable protein supply enhanced growth performance and led to variable results on innate and humoral immune response of preconditioning beef steers. J Anim Sci. 2015;93:4473-85.

21. Andrew S. FastQC a quality control tool for high throughput sequence data. 2010;

22. Langmead B, Salzberg SL. Fast gapped-read alignment with bowtie 2. Nat Methods. 2012;9:357-9.

23. Liao Y, Smyth GK, Shi W. FeatureCounts: an efficient general purpose program for assigning sequence reads to genomic features. Bioinformatics. 2014;30:923-30.

24. Robinson MD, Oshlack A. others. A scaling normalization method for differential expression analysis of RNA-seq data. Genome Biol. 2010;11:R25.

25. Di Y, Schafer DW, Cumbie JS, Chang JH. The NBP negative binomial mode for assessing differential gene expression from RNA-Seq. Stat Appl Genet Mol Biol. 2011;10:1-28.

26. Simon A, Wolfgang $H$. Differential expression analysis for sequence count data. Genome Biol. 2011;11:R106.
27. R Development Core Team. R: A language and environment for statistical computing. R Foundation for Statistical Computing, Vienna, Austria [Internet]. 2008. Available from: http://www.r-project.org

28. Benjamin Y, Hochberg Y. Cntrolling the false discovery rate: a practical and powerful approach to multiple testing. J R Stat Soc. 1995;57:289-300.

29. Mi H, Huang X, Muruganujan A, Tang H, Mills C, Kang D, Thomas PD. PANTHER version 11: expanded annotation data from gene ontology and Reactome pathways, and data analysis tool enhancements. Nucleic Acids Res. 2017:45:D183-9.

30. Kim S. ppcor: an R package for a fast calculation to smi-partial correlation coefficients. Commun Stat Appl Methoods. 2015;22:665-74.

31. Epskamp S, Cramer AOJ, Waldorp LJ, Schmittmann VD, Borsboom D. qgraph: network visualizations of relationships in psychometric data. J Stat Softw. 2012;48.

32. Funston RN, Larson DM, Vonnahme KA. Effects of maternal nutrition on conceptus growth and offspring performance: implications for beef cattle production. J Anim Sci. 2010:88.

33. Dodic M, Abouantoun T, O'Connor A, Wintour EM, Moritz KM. Programming effects of short prenatal exposure to dexamethasone in sheep. Hypertension. 2002;40:729-34.

34. Gilbert JS, Ford SP, Lang AL, Pahl LR, Drumhiller MC, Babcock SA, Nathanielsz PW, Nijland MJ. Nutrient restriction impairs nephrogenesis in a gender-specific manner in the ovine fetus. Pediatr Res. 2007:61:42-7.

35. Micke GC, Sullivan TM, Gatford KL, Owens JA, Perry VEA. Nutrient intake in the bovine during early and mid-gestation causes sex-specific changes in progeny plasma IGF-I, liveweight, height and carcass traits. Anim Reprod Sci. 2010;121:208-17.

36. Gionbelli TRS, Veloso CM, Rotta PP, Valadares Filho SC, C. Carvalho B, Marcondes MI, S. Cunha C, Novaes MAS, Prezotto LD, Duarte MS, Gionbelli MP. Foetal development of skeletal muscle in bovines as a function of maternal nutrition, foetal sex and gestational age. J Anim Physiol Anim Nutr (Berl). 2017:1-12.

37. Ambrosio R, De Stefano MA, Di Girolamo D, Salvatore D. Thyroid hormone signaling and deiodinase actions in muscle stem/progenitor cells. Mol Cell Endocrinol. 2017;459:79-83.

38. Oster M, Murani E, Metges CC, Ponsuksili S, Wimmers K. Transcriptional response of skeletal muscle to a low-protein gestation diet in porcine offspring accumulates in growth- and cell cycle-regulating pathways. Physiol Genomics. 2012;44:811-8.

39. Yang $Y$, Liang G, Niu G, Zhang Y, Zhou R, Wang Y, Mu Y, Tang Z, Li K. Comparative analysis of DNA methylome and transcriptome of skeletal muscle in lean-, obese-, and mini-type pigs. Sci Rep. 2017;7:1-14.

40. Daniel ZCTR, Brameld JM, Craigon J, Scollan ND, Buttery PJ. Effect of maternal dietary restriction during pregnancy on lamb carcass characteristics and muscle fiber composition. J Anim Sci. 2007:85: $1565-76$

41. Zheng J. Energy metabolism of cancer: glycolysis versus oxidative phosphorylation (review). Oncol Lett. 2012;4:1151-7.

42. Byrne KA, Wang YH, Lehnert SA, Harper GS, McWilliam SM, Bruce HL, Reverter A. Gene expression profiling of muscle tissue in Brahman steers during nutritional restriction. J Anim Sci. 2005;83:1-12.

43. Raja JS, Hoffman ML, Govoni KE, Zinn SA, Reed SA. Restricted maternal nutrition alters myogenic regulatory factor expression in satellite cells of ovine offspring. Animal. 2016;10:1200-3.

44. Ding Q, Kang J, Dai J, Tang M, Wang Q, Zhang H, Guo W, Sun R, Yu H. AGXT2L1 is down-regulated in heptocellular carcinoma and associated with abnormal lipogenesis. J Clin Pathol. 2016;69:215-20.

45. Lau P, Fitzsimmons RL, Pearen MA, Watt MJ, Muscat GEO. Homozygous staggerer $(\mathrm{sg} / \mathrm{sg}$ ) mice display improved insulin sensitivity and enhanced glucose uptake in skeletal muscle. Diabetologia. 2011;54:1169-80.

46. Nagaos M, Parimoo B, Tanaka K. Masayoshi NagaoS, Bhama Parimoo, and Kay Tanaka4. J Biol Chem. 1993;268:24114-24.

47. Schweizer L, Varmus H. Wnt / wingless signaling through beta-catenin requires the function of both LRP / arrow and frizzled classes of receptors. BMC Cell Biol. 2003;4:1-11

48. Tiffin GJ, Rieger D, Betteridge KJ, Yadav BR, King WA. Glucose and glutamine metabolism in pre-attachment cattle embryos in relation to sex and stage of development. J Reprod Fertil. 1991;93:125-32.

49. Bermejo-Alvarez P, Rizos D, Rath D, Lonergan P, Gutierrez-Adan A. Sex determines the expression level of one third of actively expressed genes in bovine blastocysts. PNAS. 2010;107. 
50. Roda-navarro P, Arce I, Renedo M, Montgomery K, Kucherlapati R, FernandezRuiz E. Human KLRF1, a novel member of the killer cell lectin-like receptor gene family : molecular characterization, genomic structure, physical mapping to the NK gene complex and expression analysis. Eur J Immunol. 2000;30:568-76.

51. Laoukili J, Kooistra MR, Bras A, Kauw J, Kerkhoven RM, Morrison A, Clevers H, Medema $\mathrm{RH}$. FoxM1 is required for execution of the mitotic programme and chromosome stability. Nat Cell Biol. 2005;7:126-36.

52. Melchjorsen J, Kristiansen H, Christiansen R, Rintahaka J, Matikainen S, Paludan SR, Hartmann R. Differential regulation of the OASL and OAS1 genes in response to viral infections. J Interf Cytokine Res. 2009;29:199-207.

53. Pace $M$, Graham E. The release of glutamic oxaloacetic transaminase from bovine spermatozoa as a test method of assessing semem quality and fertility. Biol Reprod. 1970;3:140-6.

54. Yamauchi T, Nakamura N, Hiramoto M, Yuri M, Yokota H, Naitou M, Takeuchi M, Yamanaka K, Kita A, Nakahara T, Kinoyama I, Matsuhisa A, Kaneko N, Koutoku H, Sasamata M, Kobori M, Katou M, Tawara S, Kawabata S, et al. Sepantronium bromide (YM155) induces disruption of the ILF3/ p54nrbcomplex, which is required for survivin expression. Biochem Biophys Res Commun. 2012:425:711-6.

55. MacDonald ME, Anderson MA, Lockyer JL, Milstien S, Hobbs WJ, Faryniarz AG, Kaufman S, Ledley FD, Woo SLC, Gusella JF. Physical and genetic localization of quinonoid dihydropteridine reductase gene (QDPR) on short arm of chromosome 4. Somat Cell Mol Genet. 1987;13:569-74.

56. Roussel-Gervais A, Couture C, Langlais D, Takayasu S, Balsalobre A, Rueda BR, Zukerberg LR, Figarella-Branger D, Brue T, Drouin J. The cables1 gene in glucocorticoid regulation of pituitary corticotrope growth and Cushing disease. J Clin Endocrinol Metab. 2016;101:513-22.

57. Dalton WS, Scheper RJ. Lung resistance-related protein: determining its role in multidrug resistance. J Natl Cancer Inst. 1999;91:1604-5.

58. Hopkins PCR. Neurodegeneration in a Drosophila model for the function of TMCC2, an amyloid protein precursor-interacting and Apolipoprotein Ebinding protein. PLoS One. 2013;8.

59. Aridon P, De Fusco M, Winkelmann JW, Zucconi M, Arnao V, Ferini-Strambi $L$, Casari G. A TRAPPC6B splicing variant associates to restless legs syndrome. Park Relat Disord. 2016;31:135-8.

60. Escudero E, Mora L, Fraser PD, Aristoy M, Toldrá F. Identification of novel antioxidant peptides generated in Spanish dry- cured ham. Food Chem. 2012;138:1282-8.

61. Hall C, Sin WC, Teo M, Michael GJ, Smith P, Dong JM, Lim HH, Manser E, Spurr NK, Jones TA, Lim L. Alpha 2-chimerin, an SH2-containing GTPaseactivating protein for the ras-related protein p21 rac derived by alternate splicing of the human $\mathrm{n}$-chimerin gene, is selectively expressed in brain regions and testes. Mol Cell Biol. 1993;13:4986-98.

62. Benfenati V, Caprini M, Dovizio M, Mylonakou MN, Ferroni S, Ottersen OP, Amiry-Moghaddam M. An aquaporin-4/transient receptor potential vanilloid 4 (AQP4/TRPV4) complex is essential for cell-volume control in astrocytes. Proc Natl Acad Sci U S A. 2011;108:2563-8.

63. York PS, Cummins SF, Degnan SM, Woodcroft BJ, Degnan BM. Identification of genes differentially expressed in the ganglia of growing Haliotis asinina. J Shellfish Res. 2010;29:741-52.

64. Bassani S, Passafaro M. Tspan7. BioArchitecture. 2012;2:95-7.

65. Lin J, Weiss A, Timothy S, Finco TS. Localization of LAT in for T cell activation. J Biol Chem. 1999;274:28861-5.

66. Amati B, Littlewood TD, Evan Gl, Land H. The c-Myc protein induces cell cycle progression and apoptosis through dimerization with max. EMBO J. 1993;12:5083-7

67. Suls A, Dedeken P, Goffin K, Van Esch H, Dupont P, Cassiman D, Kempfle J, Wuttke TV, Weber Y, Lerche H, Afawi Z, Vandenberghe W, Korczyn AD, Berkovic SF, Ekstein D, Kivity S, Ryvlin P, Claes LRF, Deprez L, et al. Paroxysmal exercise-induced dyskinesia and epilepsy is due to mutations in SLC2A1, encoding the glucose transporter GLUT1. Brain. 2008;131:1831-44.

68. Zou Y, Donkervoort S, Salo AM, Foley AR, Barnes AM, Hu Y, Makareeva E, Leach ME, Mohassel P, Dastgir J, Deardorff MA, Cohn RD, DiNonno WO, Malfait F, Lek M, Leikin S, Marini JC, Myllyharju J, Bönnemann CG. P4HA1 mutations cause a unique congenital disorder of connective tissue involving tendon, bone, muscle and the eye. Hum Mol Genet. 2017;26:2207-17.

69. Dupont S, Mamidi A, Cordenonsi M, Montagner M, Zacchigna L, Adorno M, Martello G, Stinchfield MJ, Soligo S, Morsut L, Inui M, Moro S, Modena N, Argenton F, Newfeld SJ, Piccolo S. FAM/USP9x, a Deubiquitinating enzyme essential for TGF $\beta$ signaling, controls Smad4 Monoubiquitination. Cell. 2009; 136:123-35
70. Hemming S, Cakouros D, Isenmann S, Cooper L, Menicanin D, Zannettino A, Gronthos S. EZH2 and KDM6A act as an epigenetic switch to regulate Mesenchymal stem cell lineage specification. Stem Cells. 2014;32:802-15.

71. Gregory L, Ferreira C, Williams H, Rahman S, Alatzoglou K, Kapoor R, Jones P, Hussain K, Gaston-Massuet C, Qasim W, Dattani M, Qasim, W, Dattani, M.T. A novel mutation in eukaryotic translation initiation factor 2 subunit 3 (EIF2S3) is associated with severe hypoglycaemia and $x$-linked hypopituitarism. Endocr Rev. 2016;37:2-3.

72. Stiles AR, Russell DW. SRD5A3: a surprising role in glycosylation. Cell. 2010; 142:196-8.

73. Yang J, Kulkarni K, Manolaridis I, Zhang Z, Dodd RB, Mas-Droux C, Barford D. Mechanism of Isoprenylcysteine carboxyl methylation from the crystal structure of the integral membrane methyltransferase ICMT. Mol Cell. 2011;44:997-1004.

74. Xiao Y, Wu Y, Sun K, Feng J. Cell proliferation: a potential compensatory mechanism for tissue damage during hibernation. Musculoskelet Regen. 2016;2:2-4.

75. Ciccia A, Ling C, Coulthard R, Yan Z, Xue Y, Meetei AR, Laghmani EH, Joenje H, McDonald N, de Winter JP, Wang W, West SC. Identification of FAAP24, a Fanconi Anemia Core complex protein that interacts with FANCM. Mol Cell. 2007;25:331-43.

76. Kanda M, Shimizu D, Fujii T, Sueoka S, Tanaka Y, Ezaka K, Takami H, Tanaka H, Hashimoto R, Iwata N, Kobayashi D, Tanaka C, Yamada S, Nakayama G, Sugimoto $H$, Koike M, Fujiwara M, Kodera Y. Function and diagnostic value of Anosmin-1 in gastric cancer progression. Int J Cancer. 2016;138:721-30.

77. Kim E, Nishimura H, Baba T. Differential localization of ADAM1a and ADAM1b in the endoplasmic reticulum of testicular germ cells and on the surface of epididymal sperm. Biochem Biophys Res Commun. 2003;304:313-9.

78. Flores-Alcantar A, Gonzalez-Sandoval A, Escalante-Alcalde D, Lomelí H. Dynamics of expression of ARID1A and ARID1B subunits in mouse embryos and in cells during the cell cycle. Cell Tissue Res. 2011;345:137-48.

79. Lee $Y H$, Wang $M-Y, Y u X-X$, Unger RH. Glucagon is the key factor in the development of diabetes. Diabetologia. 2016:59:1372-5.

80. Sisodiya SM, Thompson PJ, Need A, Harris SE, Weale ME, Wilkie SE, Michaelides M, Free SL, Walley N, Gumbs C, Gerrelli D, Ruddle P, Whalley LJ, Starr JM, Hunt DM, Goldstein DB, Deary IJ, Moore AT. Genetic enhancement of cognition in a kindred with cone-rod dystrophy due to RIMS1 mutation. J Med Genet. 2007:44:373-80.

81. Charmley P, Weil S, Sanall O, Malhotra U, Concannon P, Terhorst C, Gatti RA. Human T-cell receptor CD3-y (CD3G) / Mspl DNA polymorphism. Nucleic Acids Res. 1989;17:8042.

82. Howcroft TK, Murphy C, Weissman JD, Huber SJ, Sawadogo M, Singer DS. Upstream stimulatory factor regulates major histocompatibility complex class I gene expression: the U2DeltaE4 splice variant abrogates E-box activity. Mol Cell Biol. 1999;19:4788-97.

83. Tsujishita Y, Hurley JH. Structure and lipid transport mechanism of a StARrelated domain. Nat Struct Biol. 2000;7:408-14.

84. DeWald DB, Torabinejad J, Samant RS, Johnston D, Erin N, Shope JC, Xie Y, Welch DR. Metastasis suppression by breast cancer metastasis suppressor 1 involves reduction of phosphoinositide signaling in MDA-MB-435 breast carcinoma cells. Cancer Res. 2005;65:713-7.

85. Spinazzola A, Viscomi C, Fernandez-Vizarra E, Carrara F, D'Adamo $P$, Calvo S, Marsano RM, Donnini C, Weiher H, Strisciuglio P, Parini R, Sarzi E, Chan A, DiMauro S, Rotig A, Gasparini P, Ferrero I, Mootha VK, Tiranti $V$, et al. MPV17 encodes an inner mitochondrial membrane protein and is mutated in infantile hepatic mitochondrial DNA depletion. Nat Genet. 2006;38:570-5.

86. Chen J, Lu Y, Xu J, Huang Y, Cheng H, Hu G, Luo C, Lou M, Cao G, Xie Y, Ying K. Identification and characterization of NBEAL1, a novel human neurobeachin-like 1 protein gene from fetal brain, which is up regulated in glioma. Mol Brain Res. 2004;125:147-55.

87. Lee MO, Kim E-H, Jang H-J, Park MN, Woo H-J, Han JY, Womack JE. Effects of a single nucleotide polymorphism in the chicken NK-lysin gene on antimicrobial activity and cytotoxicity of cancer cells. Proc Natl Acad Sci U S A. 2012;109:12087-92.

88. Mukhopadhyay S, Wen X, Ratti N, Loktev A, Rangell L, Scales SJ, Jackson PK. The ciliary G-protein-coupled receptor Gpr161 negatively regulates the sonic hedgehog pathway via CAMP signaling. Cell. 2013;152:210-23.

89. Chambers J, Ames RS, Bergsma D, Muir A, Fitzgerald LR, Hervieu G, Dytko GM, Foley JJ, Martin J, Liu WS, Park J, Ellis C, Ganguly S, Konchar S, Cluderay J, Leslie R, Wilson S, Sarau HM. Melanin-concentrating hormone is the cognate ligand for the orphan G- protein-coupled receptor SLC-1. Nature. 1999;400:261-5. 
90. Rozycka M, Lu YJ, Brown RA, Lau MR, Shipley JM, Fry MJ. cDNA cloning of a third human C2-domain-containing class II phosphoinositide 3-kinase, PI3K-C2 gamma, and chromosomal assignment of this gene (PIK3C2G) to 12 p12. Genomics. 1998:54:569-74.

91. Williamson MP. The structure and function of proline-rich regions in proteins. Biochem J. 1994;297:249-60.

92. Chen HHW, Kuo MT. Overcoming platinum drug resistance with copperlowering agents. Anticancer Res. 2013;33:4157-62.

93. Sheng Y, Tsai-Morris CH, Gutti R, Maeda Y, Dufau ML. Gonadotropinregulated testicular RNA helicase (GRTH/Ddx25) is a transport protein involved in gene-specific mRNA export and protein translation during spermatogenesis. J Biol Chem. 2006;281:35048-56.

Ready to submit your research? Choose BMC and benefit from:

- fast, convenient online submission

- thorough peer review by experienced researchers in your field

- rapid publication on acceptance

- support for research data, including large and complex data types

- gold Open Access which fosters wider collaboration and increased citations

- maximum visibility for your research: over $100 \mathrm{M}$ website views per year

At BMC, research is always in progress.

Learn more biomedcentral.com/submissions 